University of South Florida

DIGITAL COMMONS

Digital Commons @ University of

@ UNIVERSITY OF SOUTH FLORIDA

South Florida

$1-1-2015$

\title{
2015 Accountability Report USF Tampa
}

USF

Follow this and additional works at: https://digitalcommons.usf.edu/usf_accountability_reports

\section{Scholar Commons Citation}

USF, "2015 Accountability Report USF Tampa" (2015). USF Accountability Reports. 52.

https://digitalcommons.usf.edu/usf_accountability_reports/52

This Article is brought to you for free and open access by the USF Archives at Digital Commons @ University of South Florida. It has been accepted for inclusion in USF Accountability Reports by an authorized administrator of Digital Commons @ University of South Florida. For more information, please contact digitalcommons@usf.edu. 


\section{4-15}

\section{Annual Accountability Report}

\section{UNIVERSITY OF SOUTH FLORIDA TAMPA}

BOT APPROVED 3/3/2016

STATE UNIVERSITY SYSTEM of FLORIDA Board of Governors 


\section{TABLE OF CONTENTS}

\section{EXECUTIVE SUMMARY}

DASHBOARD

KEY ACHIEVEMENTS

NARRATIVE p. 2

p. 5

p. 6

\section{DATA TABLES}

SECTION 1. FINANCIAL RESOURCES p. 12

SECTION 2. PERSONNEL

p. 16

SECTION 3. ENROLLMENT

p. 17

SECTION 4. UNDERGRADUATE EDUCATION

p. 21

SECTION 5. GRADUATE EDUCATION

p. 30

SECTION 6. RESEARCH \& ECONOMIC DEVELOPMENT

p. 32 


\section{Dashboard}

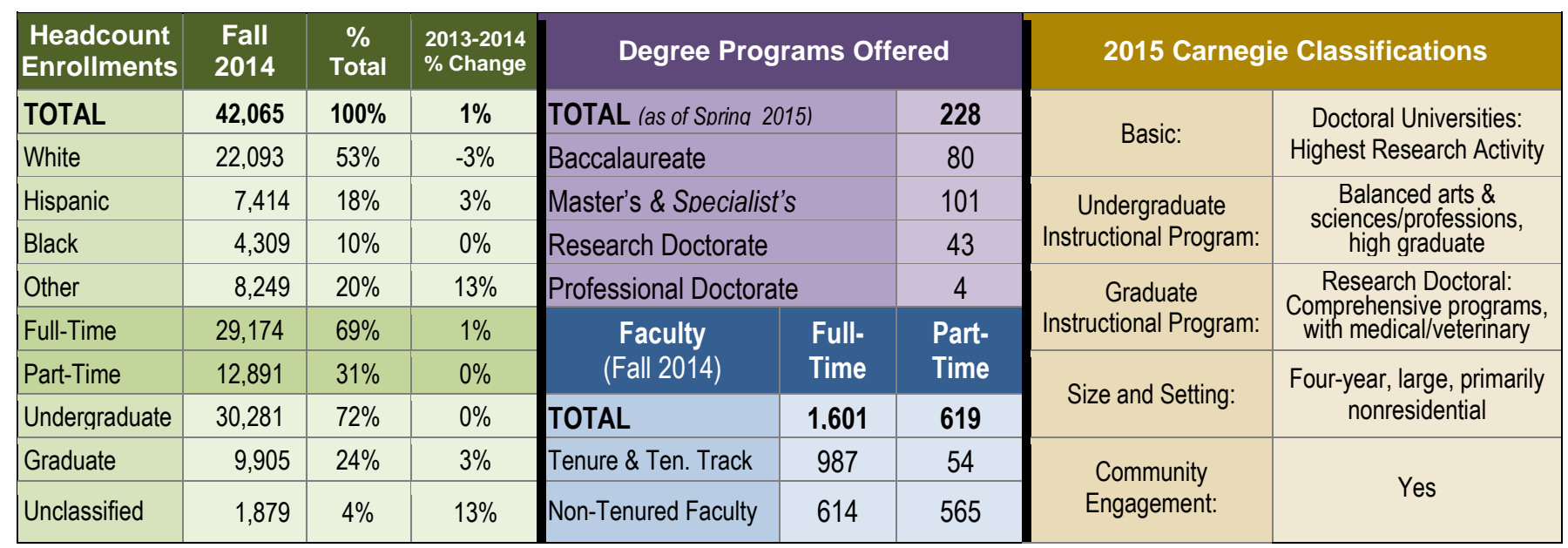

\section{DEGREE PRODUCTIVITY AND PROGRAM EFFICIENCY}

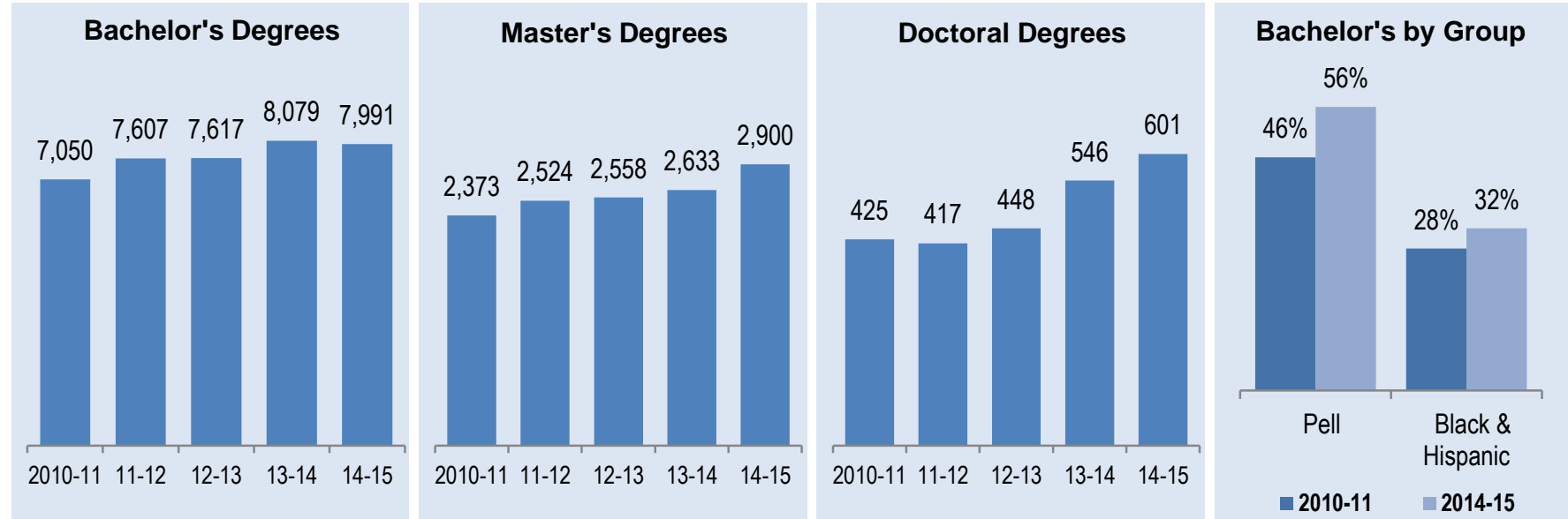

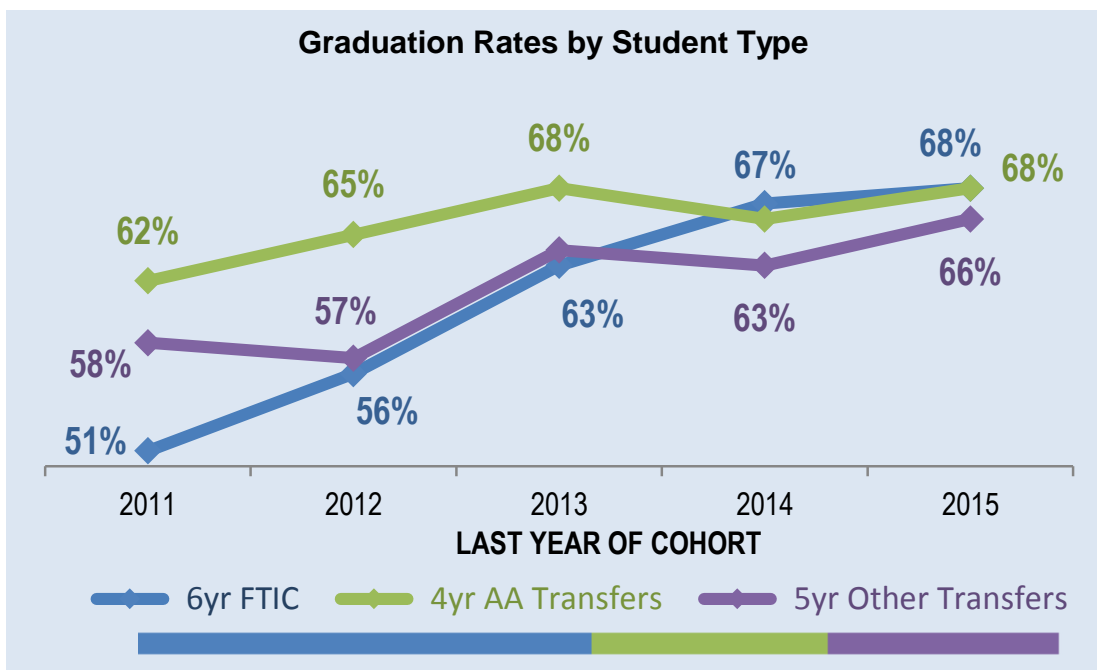

PROPORTION OF STUDENTS IN COHORTS ENDING IN 2015

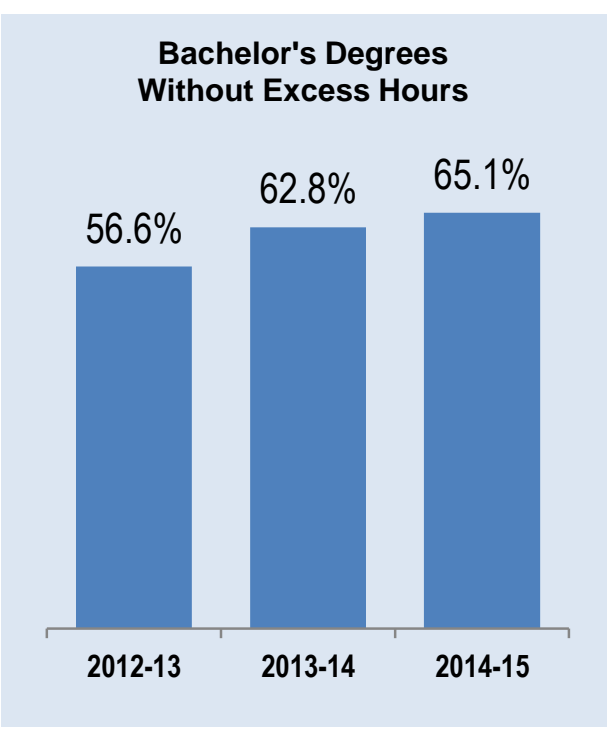




\section{Dashboard}

\section{DEGREES AWARDED IN PROGRAMS OF STRATEGIC EMPHASIS (PSE)}
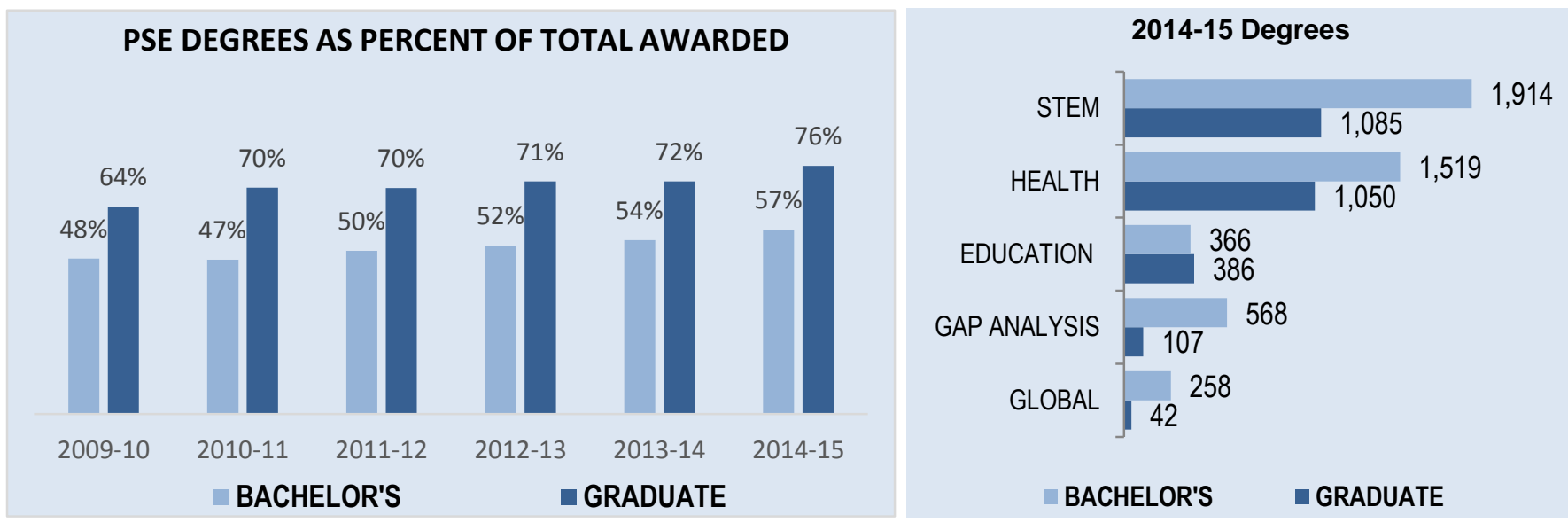

\section{RESEARCH AND COMMERCIALIZATION ACTIVITY}

Total R\&D Expenditures (\$ Millions)

with Percent Funded Externally

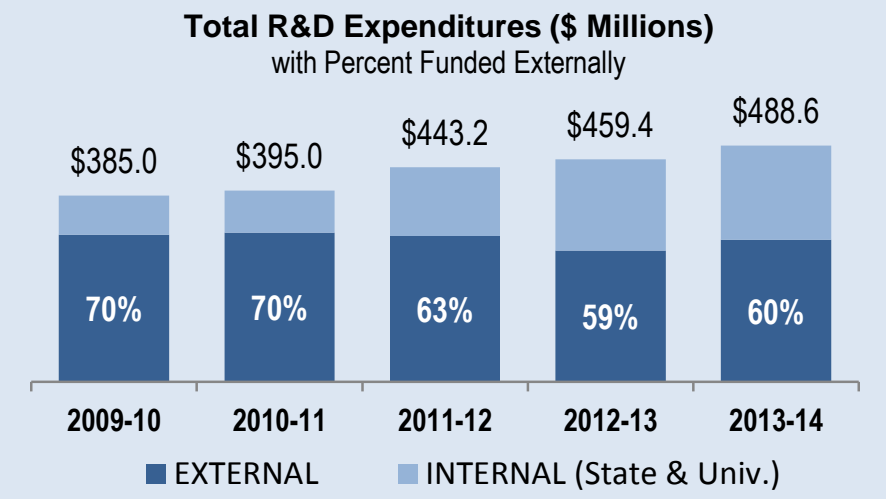

\section{Licenses and Licensing Revenue}

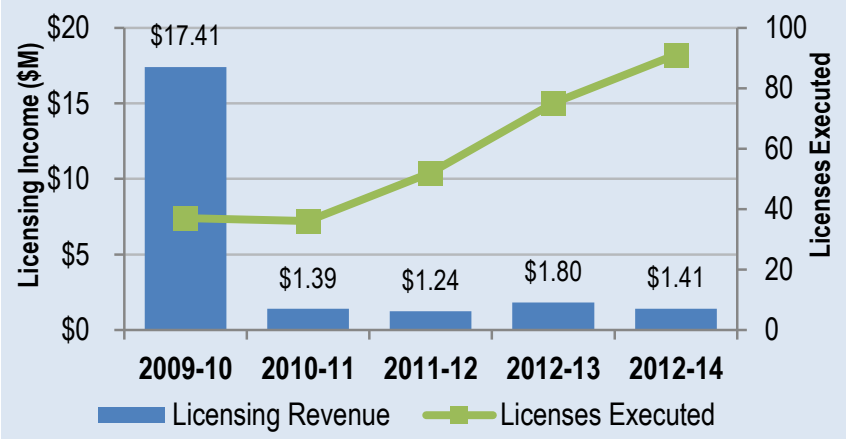

\section{RESOURCES}

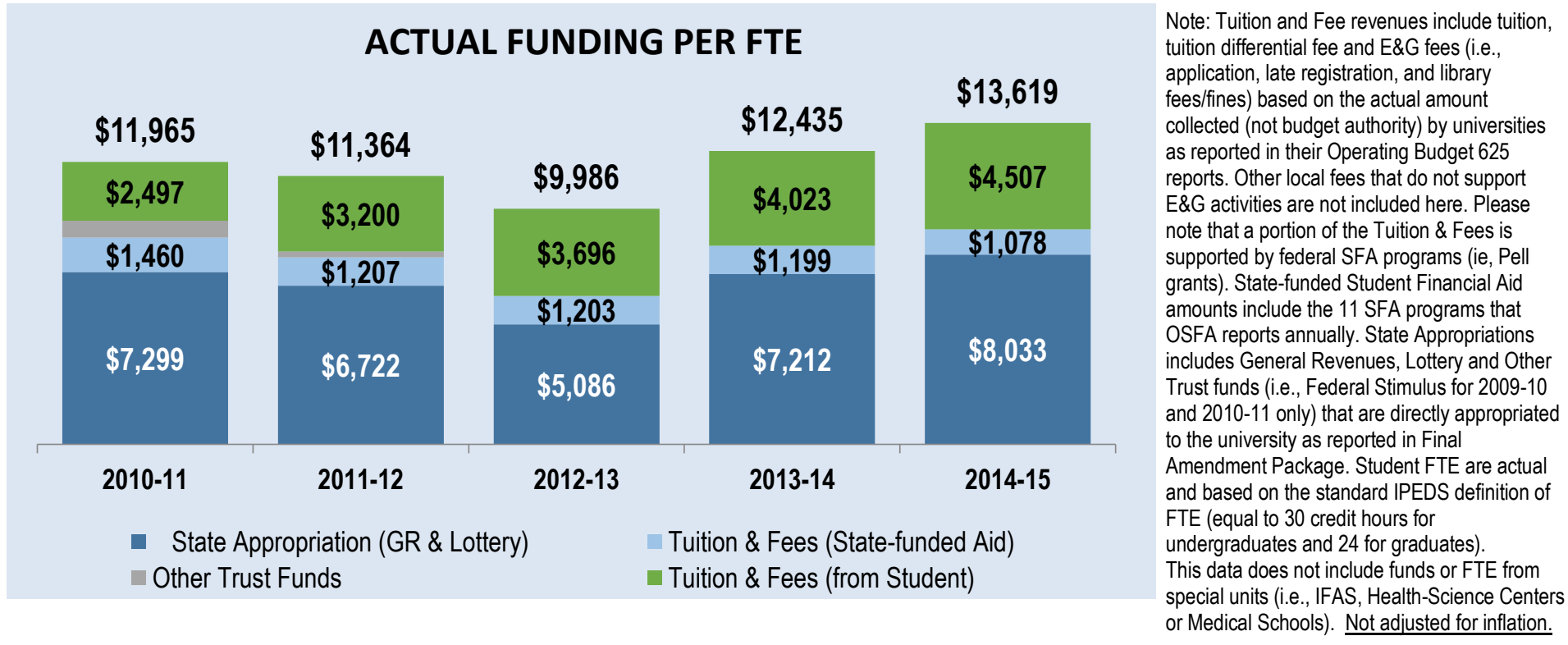




\section{Dashboard}

\section{POST-GRADUATION METRICS}

\section{Percent of Bachelor's Graduates Employed or Continuing their Education One Year After Graduation}

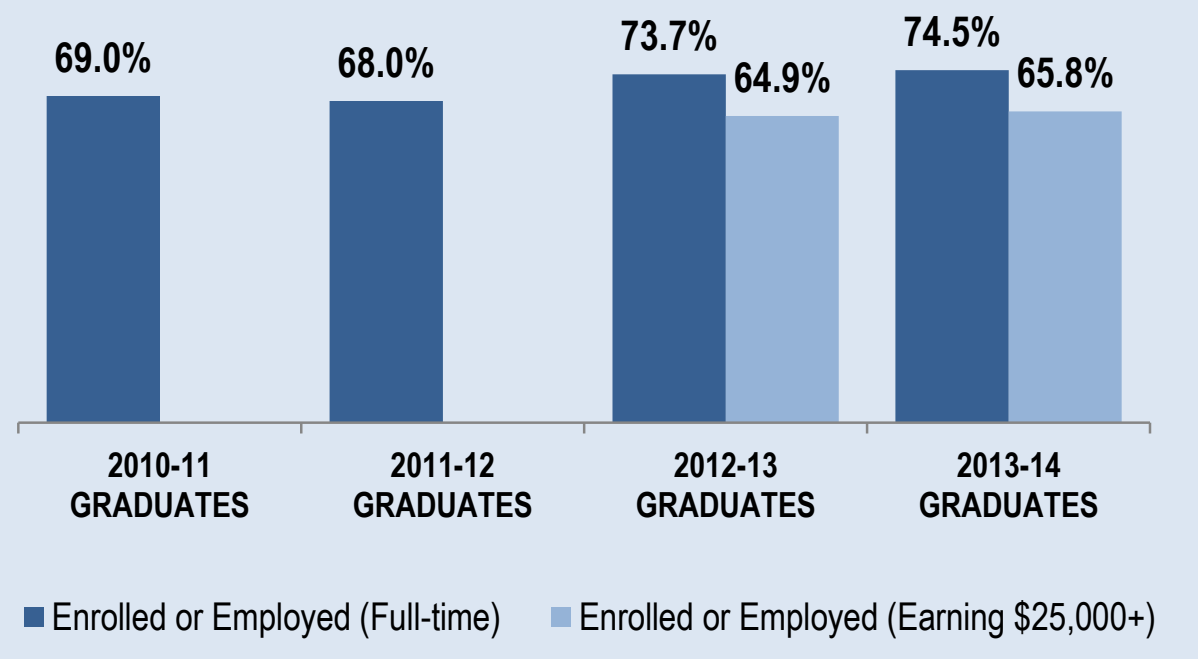

\section{Wages of Full-time Employed in Florida Baccalaureates One Year After Graduation 5th, 25th, 50th, 75th and 95th Percentiles}
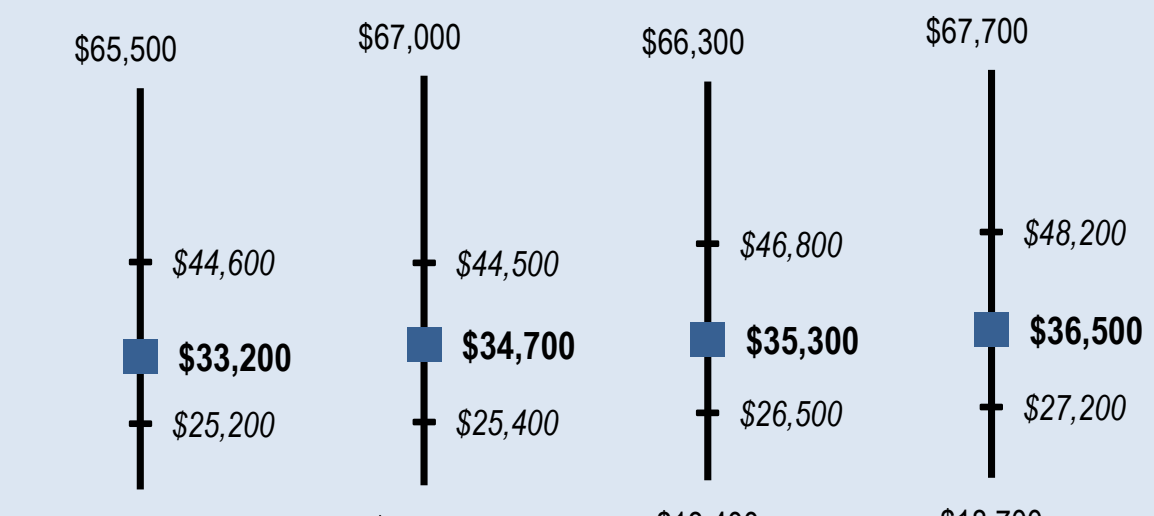

$\$ 17,300$

$\$ 17,800$

\section{$\$ 18,400$}

Notes: Percentages are based on the number of recent baccalaureate graduates who are either employed full-time or continuing their education in the U.S. (based on the National Student Clearinghouse data). Full-time employment is based on those who earned more than a full-time (40hrs a week) worker making minimum wage. Due to limitations in the data, the continuing enrollment data includes any enrollment the following year regardless of whether the enrollment was post-baccalaureate or not. BOG staff 'found' $92 \%$ of USFTampa's 2013-14 bachelor's recipients.

See Table 40 within this report for additional information about this metric.

Notes: Wage data is based on Florida's annualized Unemployment Insurance (UI) wage data for those graduates who earned more than a full-time employee making minimum wage in the fiscal quarter a full year after graduation. This UI wage data does not include individuals who are self-employed, employed out of state, employed by the military or federal government, or those without a valid social security number. In 2013-14, these data accounted for $53 \%$ of the total graduating class. This wage data includes graduates who were employed full-time (regardless of their continuing enrollment). Wages are provided for 5 th, 25th, 50th, 75th and 95th percentiles. Median wages are identified by bolded values. The interquartile range (shown in italics) represents $50 \%$ of the wage data. Wages rounded to nearest hundreds.

$\begin{array}{cccc}2010-11 & 2011-12 & 2012-13 & 2013-14 \\ \text { GRADUATES } & \text { GRADUATES } & \text { GRADUATES } & \text { GRADUATES }\end{array}$




\section{Key Achievements (2014-2015)}

Limit to one page. Please don't include achievements reported last year.

\section{STUDENT AWARDS/ACHIEVEMENTS}

1. In 2014-15 USF had a record-number of national scholarship winners with 51 . This included three Frost Scholars, USF's first ever Gates Cambridge Scholar, and a number of Fulbright, Gates, Gilman, Goldwater, Udal, NSF Graduate Research and Critical Language scholars.

2. Two additional USF student veterans were named Tillman scholars for 2015.

3. USF School of Music Ph.D. candidate Jose Valentino Ruiz produced an album that was nominated for the Latin Grammy Awards for best Latin Jazz Album.

\section{FACULTY AWARDS/ACHIEVEMENTS}

1. The American Association for the Advancement of Science named six USF faculty members as fellows - three from the USF College of Marine Science and one each from USF Health, USF College of Engineering and USF College of Arts and Sciences.

2. USF Engineering Associate Professor Daniel Yeh is utilizing his NEWgenerator waste-converter in India for the first time; the device turns waste into fertilizers, energy and clean water via a selfsustaining machine that operates off-grid.

3. The National Student Affairs Administrators in Higher Education awarded USF Vice President for Student Affairs Thomas Miller the Robert H. Shaffer Award for Academic Excellence.

\section{PROGRAM AWARDS/ACHIEVEMENTS}

1. USF's College of Pharmacy earned its first full accreditation from the Accreditation Council for Pharmacy Education; the Morsani College of Medicine was reaccredited by the Liaison Committee for Medical Education.

2. U.S. News and World Report named USF's online graduate engineering, education and business programs among the top 30 in the nation for 2015 - at No. 17, No. 20 and No. 27, respectively.

3. USF's undergraduate public health program was ranked No. 1 in College Factual's "Top 10 Veteran-Friendly Public Health Schools" list, featured in Military Times.

\section{RESEARCH AWARDS/ACHIEVEMENTS}

1. USF is now ranked No. 25 among public research universities for research expenditures and No. 2 in Florida, according to the National Science Foundation. For public and private universities, USF moved to No. 41.

2. USF's College of Arts and Sciences received a $\$ 3$ million grant from the National Science Foundation to develop and implement better teaching strategies for STEM programs.

3. With 104 patents in 2014 , USF now ranks $10^{\text {th }}$ nationally and $13^{\text {th }}$ among universities worldwide for U.S. Patents, according to the Intellectual Property Owners Association (IPO).

\section{INSTITUTIONAL AWARDS/ACHIEVEMENTS}

1. USF was ranked No. 2 most veteran-friendly university in the country by Military Times and No. 1 by Money Magazine.

2. USF was named an Innovation and Economic Prosperity University by the Association of Public and Land-grant Universities (APLU) in recognition of its strong commitment to economic engagement - one of only 18 institutions who received the designation in 2015.

3. USF was recognized as the Most Engaged Campus of the Year by the Florida Campus Compact; the university is one of only 40 public research universities nationwide designated as community engaged by the Carnegie Foundation for the Advancement of Teaching. 


\section{Narrative}

Limit narrative to one page per section (a 9pg max). Arial 11 point font.

\section{Teaching and Learning}

\section{STRENGTHEN QUALITY AND REPUTATION OF ACADEMIC PROGRAMS AND UNIVERSITIES}

The University of South Florida continues to increase the quality and reputation of its academic programs - evidenced by the record-setting upward trend of its student profile. In just 15 years, the average SAT score of incoming freshmen has improved from 1064 to 1223 (1806 on the three-part SAT), and the average high school GPA has increased from 3.49 to 4.08. Incoming ACT scores now stand at an average of 28. Approximately 700 freshmen are now enrolled in the USF Honors College, the largest intake ever, including a growing number of high school valedictorians, salutatorians, National Merit Scholars, and USF Provost Scholars. It's equally telling that this year the Morsani College of Medicine had a 24 percent increase in applicants, with 5,000 applicants vying for just 170 slots, and its first-year class of medical students has the highest average MCAT scores in the entire state of Florida.

This past year also marked the culmination of two years of preparation for USF's accreditation review from the Southern Association of Colleges and Schools - resulting in a spotless report with zero recommendations for improvement. This is something virtually unheard of in an institution so large and complex.

These kinds of academic gains strengthen USF's eligibility for membership in the Association of American Universities (AAU), preeminence status within the State University System of Florida and other prestigious national rankings.

\section{INCREASE DEGREE PRODUCTIVITY AND PROGRAM EFFICIENCY}

Maximizing efficiencies and accountability is something the USF leadership monitors closely as part of the continual data-driven performance review that guides all budget and policy decisions. This strategy has helped us maintain our leadership in the Board of Governors' performance-based funding model, allowing us to reinvest precious resources in areas that directly support student success.

USF is now leading the SUS in baccalaureate and graduate degrees awarded in areas of strategic emphasis for the state. Our six-year graduation rate remains one of the fastest rising among public research universities nationwide. Currently at 67 percent and estimated to go higher, we continue to focus on greater academic support and build a campus environment that supports and celebrates success - a strategy that has allowed us to eliminate the degree completion gap by socioeconomic status and race or ethnicity. Meanwhile our student athletes - 70 percent of whom are the first in their families to attend college - had some of the highest graduation rates in the American Athletic Conference.

Where possible, we always look to innovative new teaching strategies and online learning opportunities to support student choices and maximize efficiencies. USF's Innovative Education department uses market research to determine competitiveness, target market, and optimal marketing strategies that help colleges make data-supported choices about which courses, programs or certificates will perform best in the online market. The USF System now offers 91 fully online degrees and certificates at both the 


\section{Narrative}

undergraduate and graduate levels. These programs not only provide students with options that best meet their needs and schedules, but they also offer skills that provide a competitive advantage to working professionals' continuing education.

USF also offers two fully online three-week intersessions, during winter break (Wintersession) and the first three weeks of summer (Maymester) to provide even more opportunities for students to efficiently move through their degree programs on the path toward graduation. Through these programs, USF is the first SUS institution to deliver year-round educational access to help students accelerate their path to graduation. The results have been positive as more than 2,500 USF students are currently enrolled in these fully online degree programs and over $64 \%$ USF students took at least one online class during the 2014-15 school year.

Another efficiency strategy is the USF Textbook Affordability Project (TAP), which in the past five years has collectively saved students more than $\$ 1$ million through the use of e-books, expanded course reserve options and open-access textbooks authored by USF faculty. USF is working to expand these options and support faculty members' efforts to author more open-access textbook for the benefit of students at USF and beyond. We are now working with our SUS partners to share best practices and explore cost-sharing opportunities.

As a result of efforts like these, USF now boasts one of the lowest cost-per-baccalaureate-degree in the SUS. Additionally, USF distributes more financial aid from differential tuition than any other university, and we also invest the highest proportion of state funds in the SUS (74\%) on direct student instruction and research, according to the Board of Governors most recent Expenditure Analysis.

\section{INCREASE THE NUMBER OF DEGREES AWARDED IN S.T.E.M. AND OTHER PROGRAMS OF STRATEGIC EMPHASIS}

In 2014-15, 57\% percent of the USF System's undergraduate degrees were awarded in areas of strategic emphasis, including 23\% percent in STEM. In graduate degrees, $76 \%$ percent of our degrees were in areas of strategic emphasis, including 31\% percent in STEM.

This year we graduated our first class of USF College of Pharmacy students and held the first ever commencement ceremony solely for USF Health graduates - a reflection of our commitment to supporting the health workforce in Tampa Bay and indeed across the state of Florida. It is because of this commitment that we have worked so hard to move the Morsani College of Medicine and USF Health Heart Institute to downtown Tampa to best meet the demands of our students, faculty, researchers and the health workforce. 


\section{Narrative}

\section{Scholarship, Research and Innovation STRENGTHEN QUALITY AND REPUTATION OF SCHOLARSHIP, RESEARCH AND INNOVATION}

Research, scholarship and innovative activity are key differentiators for USF. We presently rank 25th in total research expenditures among public universities and 41rd among all U.S. universities public or private by the National Science Foundation, placing us as the No. 2 academic research engine in Florida.

One of the most exciting developments this year was the naming of USF by the National Science Foundation as an Innovation Corps Site, one of only 36 nationwide. USF will receive nearly $\$ 300,000$ to build, train, and mentor teams of USF faculty and students to become successful entrepreneurs and commercialize their ideas over the next three years. The goal is to launch multiple successful start-up companies at the end of the three-year grant.

Our Student Innovation Incubator is now selecting its third class of new companies, while its 24 initial student-founded companies continue to benefit from services and mentorship of 200 CEOs willing to help the next generation of entrepreneurs.

Meanwhile the USF-grown National Academy of Inventors continues to thrive nationwide, now boasting more than 3,000 individual inventor members and fellows spanning more than 200 academic and research institutions. In 2015, 11 academic inventors were added to the ranks, including inventors from USF, the University of Florida, Florida State University, Florida International University, University of Central Florida, Moffitt Cancer Center and the Institute for Human \& Machine Cognition. The 2015 Fellows account for 5,368 issued U.S. patents, bringing the collective patents held by all NAI Fellows to more than 20,000 .

\section{INCREASE RESEARCH AND COMMERCIALIZATION ACTIVITY}

USF's annual research expenditures continue to climb, a key indicator of our booming research productivity. Annual research expenditures now total more than $\$ 440$ million - up from just over $\$ 170$ million 15 years ago.

This productivity is further evidenced by USF's impressive record in registering patents. USF has ranked among the top 15 universities worldwide for the past five years in patenting new inventions - now ranked 12th in the world for U.S. utility patents and10th nationally (13th among universities worldwide), with 104 patents registered for 2014 . There are now nearly 60 products on the market that were developed at USF, as well as nine new therapeutic drugs currently in Phase II clinical trials.

The real-world application of our discoveries and technologies shows us how our intellectual power can spark new opportunities. One especially exciting venture has been The Florida Center for Cybersecurity - known as FC2 - which was created just two years ago by the Florida Legislature and Gov. Rick Scott. FC2 this year earned a National Center of Academic Excellence designation from the National Security Agency and Department of Homeland Security. And FC2 has forged partnerships with leading national institutions such as J.P. Morgan Chase, which recently provided a $\$ 300,000$ dollar grant to fast-track the training of newly retired military personnel as cybersecurity professionals. 


\section{Narrative}

\section{INCREASE COLLABORATION AND EXTERNAL SUPPORT FOR RESEARCH ACTIVITY}

USF's future is dependent on our success in brokering mutually beneficial partnerships outside of our university community - a key tenet of the USF Strategic Plan. Of USF's total \$428M in external research funding in 2015 , nearly half came from community partnerships, mostly from private or foundation partners. Currently, USF has more than 200 active collaborative agreements in more than 60 countries with more than 170 institutions around the world, laying the foundation for the development of strengthening and enriching international educational and research experiences for both faculty and students.

One recent example of this was the selection of USF, in partnership with the Tampa Bay WaVE, as a recipient of a 2014 Regional Innovation Strategies program grants by U.S. Secretary of Commerce Penny Pritzker. USF is among 26 recipients of the $\$ 500,000$ i6 Challenge grant. Matching contributions from public and private community partners raise the total project amount to over $\$ 1$ million.

This is the second i6 grant received by the USF-led partnership, which received $\$ 1$ million in 2012 to launch the FirstWaVE Venture Center. This grant enabled 94 startup companies to participate in the accelerator program, helped raise $\$ 12.6$ million in outside capital, and created and retained 337 new local jobs. In 2014, FirstWaVE was recognized by the Hillsborough County Commission with a commendation for achievement in raising outside capital.

\section{Community and Business Engagement}

\section{STRENGTHEN QUALITY AND REPUTATION OF COMMITMENT TO COMMUNITY AND BUSINESS ENGAGEMENT}

USF's commitment to community and business engagement has been validated by several external constituencies this past year. First, USF earned the 2015 Community Engagement classification by the Carnegie Foundation for the Advancement of Teaching, which recognizes colleges and universities with an institutional focus on community engagement. USF is one of a small group of public research universities nationwide with very high research activity to be designated as community engaged. Unlike the Carnegie Foundation's other classifications that rely on national data, this is an "elective" classification - institutions participate voluntarily by submitting required materials describing the nature and extent of their engagement with the community, be it local or beyond.

USF was also named an Innovation \& Economic Prosperity University by the Association of Public and Land-grant Universities (APLU), in recognition of its strong commitment to economic engagement - one of 18 universities to receive the recognition this year, a designation held by only 48 universities nationwide, and the second university in Florida to receive the designation. The designation acknowledges universities working with public and private sector partners in their states and regions to support economic development through a variety of activities, including innovation and entrepreneurship, technology transfer, talent and workforce development, and community development.

USF is also leading an effort to reenergize the region surrounding the campus as part of the new Tampa Innovation Alliance, engaging neighbors such as Busch Gardens, Moffitt Cancer Center, Florida Hospital, the Haley VA, and the Museum of Science and Industry (MOSI) in a mutually beneficial economic revitalization. The initiative is now beginning to take shape with a recent $\$ 2$ million investment from Hillsborough County.

USF's close relationship with MOSI can also be seen in a new partnership that unites the two institutions in a number of projects to provide science, technology, engineering, art, math and medicine (STEAMM) 
education to the Tampa Bay community on a larger scale. The agreement is also designed to motivate and excite K-12 students to pursue post-secondary education in STEAMM disciplines through innovative joint programs, resources and opportunities. Subject matter may include, but is not limited to Biotechnology, Health, Cyber Security, Entrepreneurship, Engineering and Global Sustainability.

\section{INCREASE LEVELS OF COMMUNITY AND BUSINESS ENGAGEMENT}

USF's commitment to community engagement is highlighted by the 4,000 students enrolled in the nearly 200 service-learning courses offered by the university. In the past year, those students have performed 60,000 hours of service to the community which, based upon federal calculations of the value of volunteer work, means they've provided $\$ 1.25$ million dollars of community-engaged work on behalf of local organizations in service-learning classes alone. In addition to benefitting the community, these activities also enhance student success through increased academic performance, graduation rates and career preparation.

Another example of this commitment can be seen at the Muma College of Business, which has a corporate mentorship program that pairs first-generation college students with business leaders to guide them through professional development activities. The result: 100 percent of the students have a job offer at graduation.

\section{INCREASE COMMUNITY AND BUSINESS WORKFORCE}

Laser-focused on ensuring that graduates are poised for success in today's workforce, USF embarked on several new initiatives using performance-based funding to support the local workforce.

Among the most visible signs of this new investment is the revamped career resource center, which has hired several new positions designed to prepare students for today's workforce and expand relationships with local employers. These positions will focus on building additional internships for students and on integrating enhanced career-readiness initiatives into the traditional college experience. Additional funding will be used to hire staff to meet the increased demand to support all students' academic success.

Another high-profile example of this effort is the new Morsani College of Medicine and USF Health Heart Institute location in downtown Tampa. The downtown site will position the medical school in close proximity to USF Health's primary teaching and clinical affiliate, Tampa General Hospital, as well as its world-class simulation center, the USF Health Center for Advanced Medical Learning and Simulation (CAMLS) and other surrounding facilities. The investment also strengthens the university's presence in downtown Tampa's business district and allows USF Health to simultaneously expand essential educational and research programs at its main campus location. Co-locating the USF Health Heart Institute with the new MCOM building downtown will also enhance recruitment of top cardiovascular researchers, support clinical and translational research opportunities to advance public health, increase MCOM's National Institutes of Health funding levels and improve the rankings of MCOM and USF's partner, TGH. 


\section{Data Tables}

\section{FINANCIAL RESOURCES}

Table 1A. Education and General Revenues

Table 1B. Education and General Expenditures

Table 1C. Funding per Student FTE

Table 1D. Cost per Degree [New]

Table 1E. Other Budget Entities

Table 1F. Voluntary Support of Higher Education

PERSONNEL

Table 2A. Personnel Headcount

\section{ENROLLMENT}

Table 3A. Headcount Enrollment by Student Type

Table 3B. Full-time Equivalent (FTE) Enrollment

Table 3C. Enrollment by Method of Instruction

Table 3D. Headcount Enrollment by Military Status and Student Level

Table 3E. University Access Rate: Undergraduate Enrollment with Pell Grant

\section{UNDERGRADUATE EDUCATION}

Table 4A. Baccalaureate Degree Program Changes in AY 2014-2015

Table 4B. Retention Rates

Table 4C. First-Time-in-College (FTIC) Six-Year Graduation Rates (Full-time only)

Table 4D. FTIC Graduation Rates (Full- and Part-time)

Table 4E. AA Transfers Graduation Rates

Table 4F. Other Transfers Graduation Rates

Table 4G. Baccalaureate Degrees Awarded

Table 4H. Baccalaureate Degrees Awarded in Areas of Strategic Emphasis

Table 4I. Baccalaureate Degrees Awarded to Underrepresented Groups

Table 4J. Baccalaureate Degrees Without Excess Credit Hours

Table 4K. Undergraduate Course Offerings

Table 4L. Faculty Teaching Undergraduates

Table 4M. Student/Faculty Ratio

Table 4N. Licensure/Certification Exam: Nursing

Table 4O. Post-Graduation Metrics

\section{GRADUATE EDUCATION}

Table 5A. Graduate Degree Program Changes in AY 2014-2015

Table 5B. Graduate Degrees Awarded

Table 5C. Graduate Degrees Awarded in Areas of Strategic Emphasis

Table 5D. Licensure/Certification Exams: Graduate Programs

\section{RESEARCH \& ECONOMIC DEVELOPMENT}

Table 6A. Research and Development Expenditures

Table 6B. Centers of Excellence 


\section{Section 1 - Financial Resources}

TABLE 1A. University Education and General Revenues (Not Adjusted for Inflation)

\begin{tabular}{lrrrrr} 
& $\begin{array}{r}\mathbf{2 0 1 1 - 1 2} \\
\text { Actual }\end{array}$ & $\begin{array}{r}\mathbf{2 0 1 2 - 1 3} \\
\text { Actual }\end{array}$ & $\begin{array}{r}\mathbf{2 0 1 3 - 1 4} \\
\text { Actual }\end{array}$ & $\begin{array}{r}\mathbf{2 0 1 4 - 1 5} \\
\text { Actual }\end{array}$ & $\begin{array}{r}\mathbf{2 0 1 5 - 1 6} \\
\text { Estimates }\end{array}$ \\
\hline MAIN OPERATIONS & & & & & \\
\hline Recurring State Funds & $\$ 179,411,103$ & $\$ 197,695,445$ & $\$ 213,139,642$ & $\$ 239,299,211$ & $\$ 231,142,586$ \\
\hline Non-Recurring State Funds & $\$ 2,073,021$ & $-\$ 42,137,455$ & $\$ 3,190,000$ & $\$ 516,536$ & $\$ 19,625,850$ \\
\hline Tuition & $\$ 109,868,313$ & $\$ 118,200,604$ & $\$ 125,127,288$ & $\$ 133,545,681$ & $\$ 136,712,013$ \\
\hline Tuition Differential Fee & $\$ 18,917,108$ & $\$ 29,072,717$ & $\$ 28,814,565$ & $\$ 28,828,440$ & $\$ 28,587,945$ \\
\hline Misc. Fees \& Fines & $\$ 2,810,849$ & $\$ 2,568,555$ & $\$ 2,699,514$ & $\$ 3,346,143$ & $\$ 4,305,085$ \\
\hline Phosphate Research TF & $\$ 7,337,035$ & $\$ 0$ & $\$ 0$ & $\$ 0$ & $\$ 0$ \\
\hline Federal Stimulus Funds & $\$ 0$ & $\$ 0$ & $\$ 0$ & $\$ 0$ & $\$ 0$ \\
\hline SUBTOTAL & $\$ 320,417,429$ & $\$ 305,399,866$ & $\$ 372,971,009$ & $\$ 405,536,011$ & $\$ 420,373,479$
\end{tabular}

HEALTH SCIENCE CENTER / MEDICAL SCHOOL

\begin{tabular}{lrrrrr}
\hline Recurring State Funds & $\$ 63,127,971$ & $\$ 65,793,008$ & $\$ 71,529,136$ & $\$ 72,577,386$ & $\$ 72,920,145$ \\
\hline Non-Recurring State Funds & $\$ 250,000$ & $\$ 0$ & $\$ 1,409,562$ & $\$ 2,100,000$ & $\$ 1,000,000$ \\
\hline Tuition & $\$ 41,065,438$ & $\$ 48,203,644$ & $\$ 51,733,993$ & $\$ 47,109,158$ & $\$ 53,751,644$ \\
\hline Tuition Differential Fee & $\$ 1,703,379$ & $\$ 2,956,633$ & $\$ 3,248,580$ & $\$ 3,339,071$ & $\$ 3,542,332$ \\
\hline Misc. Fees \& Fines & $\$ 2,568$ & $\$ 41,978$ & $\$ 83,414$ & $\$ 107,281$ & $\$ 131,800$ \\
\hline Phosphate Research TF & $\$ 0$ & $\$ 0$ & $\$ 0$ & $\$ 0$ & $\$ 0$ \\
\hline Federal Stimulus Funds & $\$ 0$ & $\$ 0$ & $\$ 0$ & $\$ 0$ & $\$ 0$ \\
\hline SUBTOTAL & $\$ 106,149,356$ & $\$ 116,995,263$ & $\$ 128,004,685$ & $\$ 125,232,896$ & $\$ 131,345,921$ \\
\multicolumn{1}{c}{ TOTAL } & & & & & \\
\hline
\end{tabular}

Recurring State Funds: include general revenue and lottery education \& general (E\&G) appropriations and any administered funds provided by the state, including annual adjustments of risk management insurance premiums for the estimated year. This does not include technical adjustments or transfers made by universities after the appropriation. Please note: 2013-14 revenues include the non-recurring $\$ 300 \mathrm{M}$ system budget reduction. Sources: SUS Final Amendment Packages were used for actual years; and, the Allocation Summary and Workpapers were used for the estimated year. Non-Recurring State Funds: include general revenue and lottery education \& general appropriations and any administered funds provided by the state. This does not include technical adjustments or transfers made by Universities after the appropriation. Source: non-recurring appropriations section of the annual Allocation Summary and Workpapers that include all other non-recurring budget amendments allocated later in the fiscal year. Note on Performance Funding: the State investment piece of performance funding is reported in the 'Non-Recurring State Funds' and the Institutional investment piece is reported within 'Recurring State Funds'. Tuition: Actual resident \& non-resident tuition revenues collected from students, net of fee waivers. Source: Operating Budget, Report 625 Schedule I-A. Tuition Differential Fee: Actual tuition differential revenues collected from undergraduate students. Source: Operating Budget, Report $625-$ Schedule I-A. Miscellaneous Fees \& Fines: Other revenue collections include items such as application fees, late registration fees, library fines, miscellaneous revenues. This is the total revenue from Report 625 minus tuition and tuition differential fee revenues. This does not include local fees. Source: Operating Budget, Report 625 - Schedule I-A. Phosphate Research Trust Fund: State appropriation for the Florida Industrial and Phosphate Research Institute at the University of South Florida (for history years through 2012-13); beginning 2013-14 the Phosphate Research Trust Fund is appropriated through Florida Polytechnic University. Other Operating Trust Funds. For UF-IFAS and UF-HSC, actual revenues from the Incidental Trust Funds and Operations \& Maintenance Trust Fund are provided by the University of Florida. Source: Final Amendment Package. Federal Stimulus Funds: Non-recurring American Recovery and Reinvestment Act funds appropriated by the state. Source: SUS Final Amendment Package. This data is not adjusted for inflation. 


\section{Section 1 - Financial Resources (continued)}

TABLE 1B. University Education and General Expenditures (Not Adjusted for Inflation)

\begin{tabular}{lrrrrr} 
& $\mathbf{2 0 1 0 - 1 1}$ & $\mathbf{2 0 1 1 - 1 2}$ & $\mathbf{2 0 1 2 - 1 3}$ & $\mathbf{2 0 1 3 - 1 4}$ & $\mathbf{2 0 1 4 - 1 5}$ \\
\hline MAIN OPERATIONS & & & & & \\
\hline Instruction/Research & $\$ 216,495,768$ & $\$ 206,584,000$ & $\$ 251,411,459$ & $\$ 252,573,090$ & $\$ 263,825,009$ \\
\hline Administration and Support & $\$ 18,202,340$ & $\$ 19,043,513$ & $\$ 24,357,579$ & $\$ 23,063,692$ & $\$ 27,166,910$ \\
\hline PO\&M & $\$ 29,586,468$ & $\$ 30,315,270$ & $\$ 36,507,797$ & $\$ 34,406,217$ & $\$ 38,367,100$ \\
\hline Student Services & $\$ 17,063,333$ & $\$ 14,849,300$ & $\$ 13,239,624$ & $\$ 8,281,245$ & $\$ 22,651,088$ \\
\hline Library/Audio Visual & $\$ 11,219,137$ & $\$ 10,777,212$ & $\$ 7,887,471$ & $\$ 11,495,421$ & $\$ 11,509,255$ \\
\hline Other & $\$ 2,854,224$ & $\$ 6,470,660$ & $\$ 6,957,842$ & $\$ 5,869,392$ & $\$ 7,862,423$ \\
\hline TOTAL & $\mathbf{2 9 5 , 4 2 1 , 2 7 0}$ & $\mathbf{\$ 2 8 8 , 0 3 9 , 9 5 5}$ & $\mathbf{\$ 3 4 0 , 3 6 1 , 7 7 2}$ & $\mathbf{\$ 3 3 5 , 6 8 9 , 0 5 7}$ & $\mathbf{\$ 3 7 1 , 3 8 1 , 7 8 5}$
\end{tabular}

HEALTH SCIENCE CENTER / MEDICAL SCHOOL

\begin{tabular}{lrrrrr}
\hline Instruction/Research & $\$ 76,521,544$ & $\$ 76,382,108$ & $\$ 95,673,445$ & $\$ 102,295,643$ & $\$ 116,949,551$ \\
\hline Administration and Support & $\$ 6,375,343$ & $\$ 5,076,837$ & $\$ 8,132,708$ & $\$ 6,263,326$ & $\$ 7,116,200$ \\
\hline PO\&M & $\$ 1,373,059$ & $\$ 1,800,847$ & $\$ 7,019,397$ & $\$ 7,391,135$ & $\$ 11,558,700$ \\
\hline Library/Audio Visual & $\$ 2,437,820$ & $\$ 3,043,160$ & $\$ 2,921,295$ & $\$ 2,587,261$ & $\$ 2,961,575$ \\
\hline Teaching Hospital \& Clinics & $\$ 0$ & $\$ 0$ & $\$ 0$ & $\$ 0$ & $\$ 0$ \\
Student Services, and Other & $\$ 1,640$ & $\$ 0$ & $\$ 0$ & $\$ 0$ & $\$ 4,686$ \\
\hline TOTAL & $\$ 86,709,406$ & $\$ 86,302,952$ & $\$ 113,746,845$ & $\$ 118,537,365$ & $\$ 138,590,712$
\end{tabular}

TOTAL $\$ 382,130,676 \quad \$ 374,342,907 \quad \$ 454,108,617 \quad \$ 454,226,422 \quad \$ 509,972,497$

The table reports the actual and estimated amount of expenditures from revenues appropriated by the legislature for each fiscal year. The expenditures are classified by Program Component (e.g., Instruction/Research, PO\&M, Administration, etc...) for activities directly related to instruction, research and public service. The table does not include expenditures classified as non-operating expenditures (e.g., to service asset-related debts), and therefore excludes a small portion of the amount appropriated each year by the legislature. Note*: FY 2012-2013 reflects a change in reporting expenditures from prior years due to the new carry-forward reporting requirement as reflected in the 2013-2014 SUS Operating Budget Reports. Since these expenditures will now include carry-forward expenditures, these data are no longer comparable to the current-year revenues reported in table $1 \mathrm{~A}$, or prior year expenditures in table 1B. This data is not adjusted for inflation.

Instruction \& Research: Includes expenditures for state services related to the instructional delivery system for advanced and professional education. Includes functions such as; all activities related to credit instruction that may be applied toward a postsecondary degree or certificate; non-project research and service performed to maintain professional effectives; individual or project research; academic computing support; academic source or curriculum development. Source: Operating Budget Summary - Expenditures by Program Activity (or Report 645). Administration \& Support Services: Expenditures related to the executive direction and leadership for university operations and those internal management services which assist and support the delivery of academic programs. Source: Operating Budget Summary - Expenditures by Program Activity (or Report 645). P0\&M: Plant Operations \& Maintenance expenditures related to the cleaning and maintenance of existing grounds, the providing of utility services, and the planning and design of future plant expansion and modification. Student Services: Includes resources related to physical, psychological, and social well-being of the student. Includes student service administration, social and cultural development, counseling and career guidance, financial aid, and student admissions and records. Other: includes Institutes and Research Centers, Radio/TV, Museums and Galleries, Intercollegiate Athletics, Academic Infrastructure Support Organizations. Source: Operating Budget Summary - Expenditures by Program Activity (or Report 645). 


\section{Section 1 - Financial Resources (continued)}

\section{TABLE 1C. Funding per Full-Time Equivalent (FTE) Student}

\begin{tabular}{lccccc} 
& $\mathbf{2 0 1 0 - 1 1}$ & $\mathbf{2 0 1 1 - 1 2}$ & $\mathbf{2 0 1 2 - 1 3}$ & $\mathbf{2 0 1 3 - 1 4}$ & $\mathbf{2 0 1 4 - 1 5}$ \\
\hline State Appropriation (GR \& Lottery) & $\$ 7,299$ & $\$ 6,722$ & $\$ 5,086$ & $\$ 7,212$ & $\$ 8,033$ \\
Tuition \& Fees (State-funded Aid) & $\$ 1,460$ & $\$ 1,207$ & $\$ 1,203$ & $\$ 1,199$ & $\$ 1,078$ \\
Tuition \& Fees (from Student) & $\$ 2,497$ & $\$ 3,200$ & $\$ 3,696$ & $\$ 4,023$ & $\$ 4,507$ \\
Other Trust Funds & $\$ 708$ & $\$ 236$ & $\$ 0$ & $\$ 0$ & $\$ 0$ \\
\hline TOTAL & $\$ 11,965$ & $\$ 11,364$ & $\$ 9,986$ & $\$ 12,435$ & $\$ 13,619$
\end{tabular}

Notes: State Appropriations includes General Revenues and Lottery funds that are directly appropriated to the university as reported in Final Amendment Package. This does not include appropriations for special units (e.g., IFAS, Health Science Centers, and Medical Schools). Tuition and Fee revenues include tuition and tuition differential fee and E\&G fees (e.g., application, late registration, and library fees/fines) as reported on the from the Operating Budget 625 reports. Other local fees that do not support E\&G activities are not included here (see Board of Governors Regulation 7.003). To more accurately report the full contribution from the State, this table reports the state-funded financial aid separately from the tuition and fee payments universities receive from students (which may include federal financial aid dollars). The state-funded gift aid includes grants and scholarships as reported by universities to Board during the academic year in the State University Database (SUDS). Other Trust funds (e.g., Federal Stimulus for 2009-10 and 2010-11 only) as reported in Final Amendment Package. Full-time Equivalent enrollment is based on actual FTE, not funded FTE; and, does not include Health-Science Center funds or FTE. This data is based on the standard IPEDS definition of FTE, equal to 30 credit hours for undergraduates and 24 for graduates. This data is not adjusted for inflation.

\section{TABLE 1D. Cost per Degree (Full Expenditures per Bachelor's Degree)}

$$
\text { 2007-11 }
$$

$\mathrm{n} / \mathrm{a}$

$\mathrm{n} / \mathrm{a}$

$2010-14$

2011-15

TOTAL

Notes: Full expenditures include direct instructional, research and public service expenditures and the undergraduate portion of indirect expenditures (e.g., academic administration, academic advising, student services, libraries, university support, and Plant Operations and Maintenance). For each year, the full expenditures were divided by undergraduate fundable student credit hours to calculate the full expenditures per credit hour, and then multiplied by 30 credit hours to represent the annual undergraduate expenditures. The annual undergraduate expenditures for each of the four years was summed to provide an average undergraduate expenditures per (120 credit) degree. Source: State University Database System (SUDS), Expenditure Analysis: Report IV. This data is not adjusted for inflation. 


\section{Section 1 - Financial Resources (continued)}

\section{TABLE 1E. University Other Budget Entities (Dollars in Millions)}

2010-11 2011-12 2012-13

2013-14

2014-15

Auxiliary Enterprises

Revenues

Expenditures

Contracts \& Grants

\section{Revenues \\ Expenditures \\ Local Funds}

\section{Revenues}

Expenditures n/a $\$ 156,099,807$

n/a $\$ 130,615,398$
$\$ 164,909,208$

$\$ 136,370,352$
$\$ 169,423,868$

$\$ 146,226,890$
$\$ 189,606,207$

$\$ 165,021,146$

\section{Faculty Practice Plans}

\author{
Revenues \\ Expenditures
}

n/a $\$ 2$

$\$ 249,719,038$

$\$ 305,717,745$

$\$ 273,377,821$

$\$ 277,629,630$

$\$ 278,259,319$

$\$ 318,568,385 \quad \$ 331,288,630$

tice Plans

n/a

$\$ 440,170,171$

$\$ 442,694,125$
$\$ 447,582,389$
$\$ 429,935,733$

$\$ 447,582,389 \quad \$ 451,415,960 \quad \$ 431,474,934$

Notes: Revenues do not include transfers. Expenditures do not include non-operating expenditures. Auxiliary Enterprises are self-supported through fees, payments and charges. Examples include housing, food services, bookstores, parking services, health centers. Contract \& Grants resources are received from federal, state or private sources for the purposes of conducting research and public service activities. Local Funds are associated with student activity (supported by the student activity fee), student financial aid, concessions, intercollegiate athletics, technology fee, green fee, and student life \& services fee. Faculty Practice Plan revenues/receipts are funds generated from faculty practice plan activities. Faculty Practice Plan expenditures include all expenditures relating to the faculty practice plans, including transfers between other funds and/or entities. This may result in double counting in information presented within the annual report. Source: Operating Budget, Report 615. This data is not adjusted for inflation.

\section{TABLE 1F. Voluntary Support of Higher Education}

Endowment Value
(\$1000s)
Gifts Received
(\$1000s)




\section{Section 2 - Personnel}

\section{TABLE 2A. Personnel Headcount (in Fall term only)}

\begin{tabular}{lccccc} 
& $\mathbf{2 0 1 0}$ & $\mathbf{2 0 1 1}$ & $\mathbf{2 0 1 2}$ & $\mathbf{2 0 1 3}$ & $\mathbf{2 0 1 4}$ \\
\hline Full-time Employees & & & & & \\
\hline Tenured Faculty & 691 & 684 & 661 & 715 & 698 \\
Tenure-track Faculty & 309 & 338 & 329 & 293 & 289 \\
Non-Tenure Track Faculty & 466 & 457 & 469 & 842 & 614 \\
Instructors Without Faculty Status & 0 & 0 & 0 & 0 & 0 \\
Graduate Assistants/Associates & 0 & 0 & 0 & 0 & 0 \\
Non-Instructional Employees & 3,915 & 4,100 & 3,964 & 4,799 & 4,931 \\
\hline FULL-TIME SUBTOTAL & $\mathbf{5 , 3 8 1}$ & $\mathbf{5 , 5 7 9}$ & $\mathbf{5 , 4 2 3}$ & $\mathbf{6 , 6 4 9}$ & $\mathbf{6 , 5 3 2}$ \\
& & & & & \\
Part-time Employees & 53 & 45 & 55 & 25 & 38 \\
\hline Tenured Faculty & 25 & 19 & 19 & 13 & 16 \\
Tenure-track Faculty & 137 & 190 & 526 & 572 & $565^{*}$ \\
Non-Tenure Track Faculty & 3 & 0 & 0 & 0 & $0^{*}$ \\
Instructors Without Faculty Status & 2,034 & 2,026 & 1,988 & 2,055 & 2,017 \\
Graduate Assistants/Associates & 143 & 209 & 778 & 81 & 72 \\
Non-Instructional Employees & $\mathbf{2 , 3 9 2}$ & $\mathbf{2 , 4 8 9}$ & $\mathbf{3 , 3 6 6}$ & $\mathbf{2 , 7 4 6}$ & $\mathbf{2 , 7 0 8}$ \\
\hline PART-TIME SUBTOTAL & & & & & \\
\hline \multicolumn{1}{c}{ TOTAL } & $\mathbf{7 , 7 7 3}$ & $\mathbf{8 , 0 6 8}$ & $\mathbf{8 , 7 8 9}$ & $\mathbf{9 , 3 9 5}$ & $\mathbf{9 , 2 4 0}$
\end{tabular}

Note: This table is based on the annual IPEDS Human Resources Survey, and provides full- and part-time medical and non-medical staff by faculty status and primary function/occupational activity. Tenured and Tenure-Track Faculty include those categorized within instruction, research, or public service. Non-Tenure Track Faculty includes adjunct faculty (on annual and less than annual contracts) and faculty on multi-year contracts categorized within instruction, research, or public service. Instructors Without Faculty Status includes postdoctoral research associates, and individuals hired as a staff member primarily to do research on a 3-year contract without tenure eligibility categorized within instruction, research, or public service. Non-Instructional Employees includes all executive, administrative and managerial positions regardless of faculty status; as well as, other support and service positions regardless of faculty status. Note: The universities vary on how they classify adjuncts (some include them as non-tenure track faculty while others do not consider them faculty and report them as instructors without faculty status) and part-time non-instructional employees. 


\section{Section 3 - Enrollment}

TABLE 3A. Headcount Enrollment by Student Type and Level

\begin{tabular}{cccccc} 
& Fall 2010 & Fall 2011 & Fall 2012 & Fall 2013 & Fall 2014* \\
\hline TOTAL & 41,846 & 41,036 & 41,212 & 41,688 & 42,065
\end{tabular}

UNDERGRADUATE

\begin{tabular}{lccccc}
\hline FTIC (Regular Admit) & 16,239 & 15,550 & 15,231 & 15,326 & 15,478 \\
FTIC (Profile Admit) & 218 & 181 & 157 & 143 & 184 \\
AA Transfers & 8,149 & 8,489 & 8,651 & 8,615 & 8,366 \\
Other Transfers & 6,719 & 6,145 & 6,393 & 6,302 & 5,445 \\
\hline Subtotal & $\mathbf{3 1 , 3 2 5}$ & $\mathbf{3 0 , 3 6 5}$ & $\mathbf{3 0 , 4 3 2}$ & $\mathbf{3 0 , 3 8 6}$ & $\mathbf{2 9 , 4 7 3}$
\end{tabular}

GRADUATE

\begin{tabular}{lccccc}
\hline Master's & 5,935 & 5,843 & 5,884 & 6,126 & 6,300 \\
Research Doctoral & 2,289 & 2,362 & 2,336 & 2,294 & 2,226 \\
Professional Doctoral & 604 & 676 & 905 & 1,220 & 1,379 \\
Dentistry & 0 & 0 & 0 & 0 & 0 \\
Law & 0 & 0 & 0 & 0 & 0 \\
Medicine & 473 & 502 & 549 & 620 & 658 \\
Nursing Practice & 32 & 27 & 30 & 43 & 89 \\
Pharmacy & 0 & 53 & 119 & 225 & 322 \\
Physical Therapist & 99 & 94 & 207 & 332 & 310 \\
Veterinary Medicine & 0 & 0 & 0 & 0 & 0 \\
Other & 0 & 0 & 0 & 0 & 0 \\
\hline Subtotal & $\mathbf{8 , 8 2 8}$ & $\mathbf{8 , 8 8 1}$ & $\mathbf{9 , 1 2 5}$ & $\mathbf{9 , 6 4 0}$ & $\mathbf{9 , 9 0 5}$
\end{tabular}

UNCLASSIFIED

\begin{tabular}{lccccc}
\hline HS Dual Enrolled & & & & 46 & 16 \\
Other & 1,693 & 1,790 & 1,655 & 1,616 & $2,671^{*}$ \\
\hline Subtotal & $\mathbf{1 , 6 9 3}$ & $\mathbf{1 , 7 9 0}$ & $\mathbf{1 , 6 5 5}$ & $\mathbf{1 , 6 6 2}$ & $\mathbf{2 , 6 8 7}$
\end{tabular}

Note: This table reports the number of students enrolled at the university by student type categories. The determination for undergraduate, graduate and unclassified is based on the institutional class level values. Unclassified refers to a student who has not yet been formally admitted into a degree program but is enrolled. The student type for undergraduates is based on the Type of Student at Time of Most Recent Admission. The student type for graduates is based on the degree that is sought and the student CIP code.

Note*: In Fall 2014, students classified by the university as post-baccalaureate are counted as "other" unclassified for the purposes of this table. This differs from the methodology used to produce data for the online interactive enrollment tool (on the Board's website) which includes post-bacs as undergraduates regardless of degree sought. Board staff will review this definition with university staff during the Summer Data Workshop and may revise it for next year's report. 


\section{Section 3 - Enrollment (continued)}

TABLE 3B. Full-Time Equivalent (FTE) Enrollment [State Fundable only]

2012-13

State-

Funded
2013-14

State-

Actual Funded

2014-15

\begin{tabular}{lrrrrrr} 
& $\begin{array}{c}\text { State- } \\
\text { Funded }\end{array}$ & Actual & $\begin{array}{c}\text { State- } \\
\text { Funded }\end{array}$ & Actual & $\begin{array}{c}\text { State- } \\
\text { Funded }\end{array}$ & Actual \\
\hline FLORIDA RESIDENTS & \multicolumn{7}{l}{} \\
\hline Lower-Division & 8,617 & 7,837 & 8,617 & 7,685 & 8,617 & 7,572 \\
Upper-Division & 10,493 & 11,997 & 10,493 & 11,679 & 10,493 & 11,480 \\
Master's (GRAD I) & 2,775 & 3,082 & 2,775 & 3,050 & 2,775 & 2,979 \\
Doctoral (GRAD II) & 623 & 961 & 623 & 944 & 623 & \multicolumn{1}{c}{942} \\
\hline Subtotal & $\mathbf{2 2 , 5 0 8}$ & $\mathbf{2 3 , 8 7 7}$ & $\mathbf{2 2 , 5 0 8}$ & $\mathbf{2 3 , 3 5 8}$ & & $\mathbf{2 2 , 9 7 3}$
\end{tabular}

NON-FLORIDA RESIDENTS

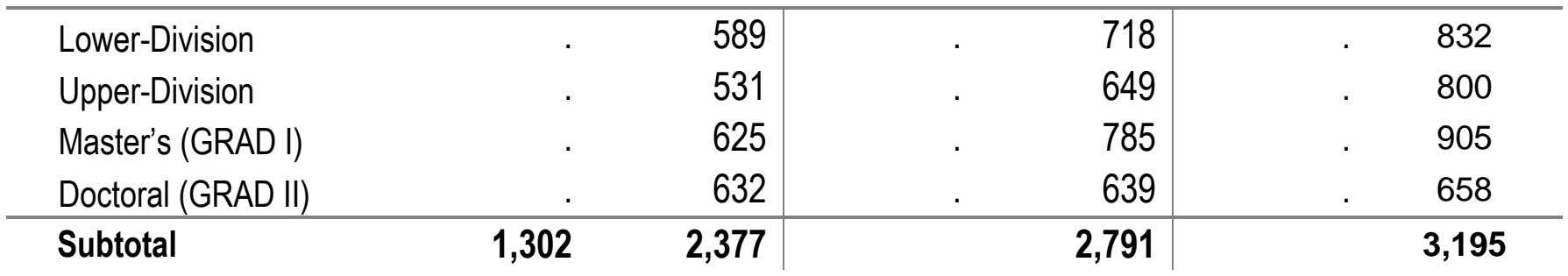

\section{TOTAL FTE}

\begin{tabular}{lrr|rr|rc}
\hline Lower-Division & 8,617 & 8,426 & 8,617 & 8,403 & 8,617 & 8,404 \\
Upper-Division & 10,493 & 12,528 & 10,493 & 12,329 & 10,493 & 12,281 \\
Master's (GRAD I) & 2,775 & 3,707 & 2,775 & 3,835 & 2,775 & 3,884 \\
Doctoral (GRAD II) & 623 & 1,593 & 623 & 1,582 & 623 & 1,600 \\
\hline Total & $\mathbf{2 3 , 8 1 0}$ & $\mathbf{2 6 , 2 5 4}$ & $\mathbf{2 2 , 5 0 8}$ & $\mathbf{2 6 , 1 4 9}$ & $\mathbf{2 2 , 5 0 8}$ & $\mathbf{2 6 , 1 6 8}$ \\
\hline Total (US Definition) & $\mathbf{3 1 , 7 4 7}$ & $\mathbf{3 5 , 0 0 5}$ & $\mathbf{3 0 , 0 1 1}$ & $\mathbf{3 4 , 8 6 5}$ & $\mathbf{3 0 , 0 1 1}$ & $\mathbf{3 4 , 8 9 1}$ \\
\hline
\end{tabular}

Notes: Full-time Equivalent (FTE) student is a measure of instructional effort (and student activity) that is based on the number of credit hours that students enroll by course level. FTE is based on the Florida definition, which divides undergraduate credit hours by 40 and graduate credit hours by 32 (US definition based on Undergraduate FTE $=30$ and Graduate FTE = 24 credit hours). In 2013-14, the Florida Legislature chose to no longer separate funded non-resident FTE from funded resident FTE. Funded enrollment as reported in the General Appropriations Act and Board of Governors' Allocation Summary. Actual enrollment only reports 'state-fundable' FTE as reported by Universities to the Board of Governors in the Student Instruction File (SIF). Totals are actual and may not equal sum of reported student levels due to rounding of student level FTE. Total FTE are equal in tables $3 \mathrm{~B}$ and $3 \mathrm{C}$.

USF provides these data 
Section 3 - Enrollment (continued)

TABLE 3C. Full-Time Equivalent (FTE) Enrollment by Method of Instruction 2010-11 2011-12 2012-13 2013-14 2014-15

TRADITIONAL

Lower-Division

Upper-Division

Master's (GRAD 1)

Doctoral (GRAD 2)

TOTAL
7,497

9,220

2,543

1,452

20,712
7,217

9,365

2,600

1,490

20,672
7,127

9,168

2,551

1,519

20,365
7,200

8,867

2,718

1,493

20,277

57

270

151

10

487
6,879

8,477

2,761

1,496

19,613

HYBRID

Lower-Division

Upper-Division

Master's (GRAD 1)

Doctoral (GRAD 2)

TOTAL

22

289

97

9

416

42

302

141

5

489

83

344

136

8

571
47

247

111

8

\section{DISTANCE LEARNING}

$\begin{array}{lrrrrr}\text { Lower-Division } & 1,292 & 1,338 & 1,216 & 1,147 & 1,478 \\ \text { Upper-Division } & 2,075 & 2,743 & 3,016 & 3,192 & 3,557 \\ \text { Master's (GRAD 1) } & 1,010 & 928 & 1,020 & 966 & 1,012 \\ \text { Doctoral (GRAD 2) } & 48 & 61 & 67 & 80 & 96 \\ \text { TOTAL } & \mathbf{4 , 4 2 5} & \mathbf{5 , 0 7 0} & \mathbf{5 , 3 1 8} & \mathbf{5 , 3 8 5} & \mathbf{6 , 1 4 2}\end{array}$

TOTAL

Lower-Division

Upper-Division

Master's (GRAD 1)

Doctoral (GRAD 2)

TOTAL

8,811
11,584
3,650
1,509

25,553

8,597
12,410
3,669
1,555
26,231

8,597
12,410

8,426

8,403

12,329

3,835

1,582

12,528

3,707

1,593

26,254

26,149

8,404

12,281

3,884

1,600

26,168

Note: Full-time Equivalent (FTE) student is a measure of instructional effort (and student activity) that is based on the number of credit hours that students enroll by course level. FTE is based on the Florida definition, which divides undergraduate credit hours by 40 and graduate credit hours by 32. Distance Learning is a course in which at least 80 percent of the direct instruction of the course is delivered using some form of technology when the student and instructor are separated by time or space, or both (per 1009.24(17), F.S.). Hybrid is a course where $50 \%$ to $79 \%$ of the instruction is delivered using some form of technology, when the student and instructor are separated by time or space, or both (per SUDS data element 2052). Traditional (and Technology Enhanced) refers to primarily face to face instruction utilizing some form of technology for delivery of supplemental course materials for no more than $49 \%$ of instruction (per SUDS data element 2052). Totals are actual and may not equal sum of reported student levels due to rounding of student level FTE. Total FTE are equal in tables $3 \mathrm{~B}$ and $3 \mathrm{C}$.

USF provides these data 


\section{Section 3 - Enrollment (continued)}

TABLE 3D. Headcount Enrollment by Military Status and Student Level

Fall $2010 \quad$ Fall $2011 \quad$ Fall $2012 \quad$ Fall $2013 \quad$ Fall 2014

\begin{tabular}{lccccc}
\hline MILITARY & \multicolumn{5}{c}{} \\
\hline Unclassified & 26 & 32 & 25 & 26 & 27 \\
Undergraduate & 699 & 773 & 827 & 830 & 885 \\
Master's (GRAD 1) & 137 & 138 & 154 & 166 & 164 \\
Doctoral (GRAD 2) & 18 & 26 & 27 & 18 & 23 \\
Subtotal & 880 & 969 & 1,033 & 1,040 & 1,099 \\
DEPENDENTS & & & & & \\
\hline Unclassified & 3 & 1 & 5 & & 2 \\
Undergraduate & 145 & 147 & 153 & 165 & 173 \\
Master's (GRAD 1) & 11 & 13 & 13 & 16 & 12 \\
Doctoral (GRAD 2) & 159 & 161 & 172 & 1 & 0 \\
Subtotal & & & & & 182 \\
NON-MILITARY & 1,664 & 1,756 & 1,625 & 1,631 & 1,850 \\
\hline Unclassified & 30,481 & 29,446 & 29,452 & 29,396 & 29,223 \\
Undergraduate & 6,231 & 6,219 & 6,366 & 6,779 & 7,091 \\
Master's (GRAD 1) & 2,431 & 2,485 & 2,564 & 2,660 & 2,615 \\
Doctoral (GRAD 2) & 40,807 & 39,906 & 40,007 & 40,466 & 40,779 \\
$\quad$ Subtotal & 41,846 & 41,036 & 41,212 & 41,688 & 42,065 \\
\hline TOTAL & & & 1 & & \\
\hline
\end{tabular}

Note: This table provides trend data on the number of students enrolled based on their military status. Military includes students who were classified as Active Duty, Veterans, National Guard, or Reservist.. Eligible Dependents includes students who were classified as eligible dependents (dependents who received veteran's benefits). Non-Military includes all other students.

\section{TABLE 3E. University Access Rate: Undergraduate Enrollment with Pell Grant}

\begin{tabular}{lccccc} 
& Fall 2010 & Fall 2011 & Fall 2012 & Fall 2013 & Fall 2014 \\
\hline Pell Grant Recipients & 12,118 & 12,607 & 12,606 & 12,498 & 12,097 \\
\hline Percent with Pell Grant & $39.19 \%$ & $42.24 \%$ & $42.40 \%$ & $42.48 \%$ & $41.71 \%$
\end{tabular}

Note: This table reports the University's Access Rate, which is a measure of the percentage of undergraduate students who have received a federal Pell grant award during a given Fall term. The top row reports the number of students who received a Pell Grant award. The bottom row provides the percentage of eligible students that received a Pell Grant award. This metric is included in the Board of Governors Performance Based Funding Model - for more information see: http://www.flbog.edu/about/budget/performance_funding.php. 


\section{Section 4 - Undergraduate Education}

\section{TABLE 4A. Baccalaureate Degree Program Changes in AY 2014-15}

\begin{tabular}{|c|c|c|c|c|c|}
\hline Title of Program & $\begin{array}{c}\text { Six-digit } \\
\text { CIP } \\
\text { Code }\end{array}$ & $\begin{array}{c}\text { Degree } \\
\text { Level }\end{array}$ & $\begin{array}{l}\text { Date of } \\
\text { UBOT } \\
\text { Action }\end{array}$ & $\begin{array}{l}\text { Starting } \\
\text { or Ending } \\
\text { Term }\end{array}$ & Comments \\
\hline \multicolumn{6}{|l|}{ New Programs } \\
\hline & & & & & \\
\hline & & & & & \\
\hline \multirow{2}{*}{\multicolumn{6}{|c|}{ Terminated Programs }} \\
\hline & & & & & \\
\hline Athletic Training & 51.0913 & Bachelors & $6 / 5 / 2014$ & FALL 2014 & \\
\hline \multicolumn{6}{|c|}{ Programs Suspended for New Enrollments } \\
\hline Information Science/Studies & 11.0401 & Bachelors & - & FALL 2010 & \\
\hline & & & & & \\
\hline & & & & & \\
\hline
\end{tabular}

Note: This table does not include new majors or concentrations added under an existing degree program CIP Code. This table reports the new and terminated program changes based on Board action dates between May 5, 2014 and May 4, 2015.

New Programs are proposed new degree programs that have been completely through the approval process at the university and, if appropriate, the Board of Governors. Does not include new majors or concentrations added under an existing degree program CIP Code.

Terminated Programs are degree programs for which the entire CIP Code has been terminated and removed from the university's inventory of degree programs. Does not include majors or concentrations terminated under an existing degree program CIP Code if the code is to remain active on the academic degree inventory.

Programs Suspended for New Enrollments are degree programs for which enrollments have been temporarily suspended for the entire CIP Code, but the program CIP Code has not been terminated. Does not include majors or concentrations suspended under an existing degree program CIP Code if the code is to remain active on the academic degree inventory and new enrollments in any active major will be reported. Programs included in this list may have been suspended for new enrollments sometime in the past and have continued to be suspended at least one term of this academic year.

New Programs Considered by University But Not Approved includes any programs considered by the university board of trustees, or any committee of the board, but not approved for implementation. Also include any programs that were returned prior to board consideration by the university administration for additional development, significant revisions, or re-conceptualization; regardless of whether the proposal was eventually taken to the university board for approval. Count the returns once per program, not multiple times the proposal was returned for revisions, unless there is a total re-conceptualization that brings forward a substantially different program in a different CIP Code. 


\section{Section 4 - Undergraduate Education (continued)}

\section{TABLE 4B. Full-time, First-Time-in-College (FTIC) Retention Rates}

\section{Retained in the Second Fall Term at Same University}

$\begin{array}{lccccc} & \mathbf{2 0 1 0 - 1 1} & \mathbf{2 0 1 1 - 1 2} & \mathbf{2 0 1 2 - 1 3} & \mathbf{2 0 1 3 - 1 4} & \mathbf{2 0 1 4 - 1 5} \\ \text { Cohort Size } & 4,477 & 3,451 & 3,825 & 3,860 & 4,117\end{array}$

Retained at USF-Tampa

\begin{tabular}{cccccc}
\hline with Any GPA & $86 \%$ & $87 \%$ & $89 \%$ & $89 \%$ & $88 \%$ \\
\hline with GPA 2.0 or higher & $82.09 \%$ & $85.02 \%$ & $86.41 \%$ & $86.74 \%$ & $85.62 \%$ \\
\hline Retained within USF-System & \multicolumn{3}{c}{} & & \\
\hline with Any GPA & $86 \%$ & $87 \%$ & $89 \%$ & $89 \%$ & $89 \%$ \\
\hline with GPA 2.0 or higher & $82.40 \%$ & $85.25 \%$ & $86.56 \%$ & $86.99 \%$ & $85.93 \%$
\end{tabular}

Notes: Cohorts are based on undergraduate students who enter the institution in the Fall term (or Summer term and continue into the Fall term). Percent Retained with Any GPA is based on student enrollment in the Fall term following their first year. Percent Retained with GPA Above 2.0 is based on student enrollment in the Fall term following their first years for those students with a GPA of 2.0 or higher at the end of their first year (Fall, Spring, Summer). The most recent year of Retention data is based on preliminary data (SIFP file) that is comparable to the final data (SIF file) but may be revised in the following years based on changes in student cohorts.

\section{TABLE 4C. Full-time, First-Time-in-College (FTIC) Six-Year Graduation Rates}

\begin{tabular}{cccccc} 
Term of Entry & $\mathbf{2 0 0 5 - 1 1}$ & $\mathbf{2 0 0 6 - 1 2}$ & $\mathbf{2 0 0 7 - 1 3}$ & $\mathbf{2 0 0 8 - 1 4}$ & $\mathbf{2 0 0 9 - 1 5}$ \\
\hline Cohort Size & 3,926 & 4,000 & 3,752 & 3,883 & 3,752 \\
\hline$\%$ Graduated & $52 \%$ & $57 \%$ & $63 \%$ & $67 \%$ & $68 \%$ \\
\hline \% Still Enrolled & $9 \%$ & $8 \%$ & $6 \%$ & $5 \%$ & $5 \%$ \\
\hline \% Success Rate & $60 \%$ & $65 \%$ & $70 \%$ & $73 \%$ & $73 \%$
\end{tabular}

Notes: Cohorts are based on FTIC undergraduate students who enter the institution in the Fall term (or Summer term and continue into the Fall term). Percent Graduated reports the percent of FTICs who graduated from the same institution within six years. This metric does not include students who enrolled as part-time students (in their first year), or who transfer into the institution. This metric complies with the requirements of the federal Student Right to Know Act that requires institutions to report the completion status at $150 \%$ of normal time (or six years). Success Rate measures the percentage of an initial cohort of students who have either graduated or are still enrolled at the same university. This data should match the IPEDS Graduation Rate Survey data that is due in late February. 


\section{Section 4 - Undergraduate Education (continued)}

TABLE 4D. Graduation Rates for First-Time-in-College (FTIC) Students

(includes Full- and Part-time students)

\begin{tabular}{lccccc}
$\mathbf{4 - \text { Year Rates }}$ & $\mathbf{2 0 0 7 - 1 1}$ & $\mathbf{2 0 0 8 - 1 2}$ & $\mathbf{2 0 0 9 - 1 3}$ & $\mathbf{2 0 1 0 - 1 4}$ & $\mathbf{2 0 1 1 - 1 5}$ \\
\hline Cohort Size & 3,933 & 4,042 & 3,831 & 4,512 & 3,477 \\
Same University & $\mathbf{3 5 \%}$ & $\mathbf{3 8 \%}$ & $\mathbf{4 2 \%}$ & $\mathbf{4 4 \%}$ & $\mathbf{5 1 \%}$ \\
\hline Other USF Institution & $0.2 \%$ & $0.3 \%$ & $0.2 \%$ & $0.3 \%$ & $0.1 \%$ \\
\hline Other University in SUS & $2 \%$ & $2 \%$ & $2 \%$ & $2 \%$ & $2 \%$ \\
\hline Total from System & $36 \%$ & $40 \%$ & $44 \%$ & $46 \%$ & $53 \%$
\end{tabular}

\begin{tabular}{cccccc}
$\mathbf{6}-$ Year Rates & $\mathbf{2 0 0 5 - 1 1}$ & $\mathbf{2 0 0 6 - 1 2}$ & $\mathbf{2 0 0 7 - 1 3}$ & $\mathbf{2 0 0 8 - 1 4}$ & $\mathbf{2 0 0 9 - 1 5}$ \\
\hline Cohort Size & 4,231 & 4,180 & 3,933 & 4,042 & 3,831
\end{tabular}

\begin{tabular}{lccccc} 
Same University & $\mathbf{5 0 . 9 8 \%}$ & $\mathbf{5 5 . 9 6 \%}$ & $\mathbf{6 2 . 5 5 \%}$ & $\mathbf{6 6 . 6 0 \%}$ & $\mathbf{6 8 . 0 8 \%}$ \\
\hline Other USF Institution & $1 \%$ & $1 \%$ & $1 \%$ & $1 \%$ & $1 \%$ \\
\hline Other University in SUS & $5 \%$ & $5 \%$ & $4 \%$ & $4 \%$ & $4 \%$ \\
\hline Total from System & $56 \%$ & $61 \%$ & $67 \%$ & $71 \%$ & $73 \%$
\end{tabular}

Notes: Cohorts are based on undergraduate students who enter the institution in the Fall term (or Summer term and continue into the Fall term). First-timein-college (FTIC) cohort is defined as undergraduates entering in fall term (or summer continuing to fall) with fewer than 12 hours earned after high school graduation. The initial cohorts can be revised to remove students, who have allowable exclusions as defined by IPEDS, from the cohort. FTIC students who are enrolled in advanced graduate degree programs that do not award a Bachelor's degree are removed from the cohorts.

Graduates are students in the cohort who have graduated by the summer term in their fourth or sixth year. Degree data often includes 'late degrees' which are degrees that were awarded in a previous term, but reported to SUDS later; so, the most recent year of data in this table only provides preliminary graduation rate data that may change with the addition of "late degrees". Late degrees reported in conjunction with the IPEDS Graduation Rate Survey due in mid-February will be reflected in the following year.

Same University provides graduation rates for students in the cohort who graduated from the same institution.

Other USF Campus provides graduation rates for students in the cohort who graduated from a different University of South Florida campus.

Other University in SUS provides graduation rates for students in the cohort who graduated from a different State University System of Florida institution. These data do not report students in the cohort who did not graduate from the SUS, but did graduate from another institution outside the State University System of Florida. 


\section{Section 4 - Undergraduate Education (continued)}

\section{TABLE 4E. Graduation Rates for AA Transfer Students from Florida College System}

\begin{tabular}{cccccc} 
Two - Year Rates & $\mathbf{2 0 0 9 - 1 1}$ & $\mathbf{2 0 1 0 - 1 2}$ & $\mathbf{2 0 1 1 - 1 3}$ & $\mathbf{2 0 1 2 - 1 4}$ & $\mathbf{2 0 1 3 - 1 5}$ \\
\hline Cohort Size & 1,815 & 1,932 & 2,009 & 1,942 & 1,984 \\
Same University & $28 \%$ & $28 \%$ & $27 \%$ & $30 \%$ & $29 \%$
\end{tabular}

\begin{tabular}{cccccc} 
Four - Year Rates & $\mathbf{2 0 0 7 - 1 1}$ & $\mathbf{2 0 0 8 - 1 2}$ & $\mathbf{2 0 0 9 - 1 3}$ & $\mathbf{2 0 1 0 - 1 4}$ & $\mathbf{2 0 1 1 - 1 5}$ \\
\hline Cohort Size & 1,711 & 1,969 & 1,815 & 1,932 & 2,009 \\
Same University & $62 \%$ & $65 \%$ & $68 \%$ & $66 \%$ & $68 \%$
\end{tabular}

Notes: AA Transfer cohort is defined as undergraduates entering in the fall term (or summer continuing to fall) and having earned an AA degree from an institution in the Florida College System. For comparability with FTIC cohorts, AA Transfer cohorts are based on undergraduate students who enter the institution in the Fall term (or Summer term and continue into the Fall term) and graduate from the same institution within two or four years.

\section{TABLE 4F. Graduation Rates for Other Transfer Students}

\begin{tabular}{cccccc}
$\mathbf{5 - Y e a r}$ Rates & $\mathbf{2 0 0 6 - 1 1}$ & $\mathbf{2 0 0 7 - 1 2}$ & $\mathbf{2 0 0 8 - 1 3}$ & $\mathbf{2 0 0 9 - 1 4}$ & $\mathbf{2 0 1 0 - 1 5}$ \\
\hline Cohort Size & 2,139 & 2,364 & 1,877 & 2,181 & 1,952 \\
Same University & $58 \%$ & $57 \%$ & $64 \%$ & $63 \%$ & $66 \%$
\end{tabular}

Notes: Other Transfer Students includes undergraduate students that transfer into a university who are not FTICs or AA Transfers. Cohorts are based on undergraduate students who enter the institution in the Fall term (or Summer term and continue into the Fall term) and graduate from the same institution within five years. 


\section{Section 4 - Undergraduate Education (continued)} TABLE 4G. Baccalaureate Degrees Awarded

\begin{tabular}{lccccc} 
& $\mathbf{2 0 1 0 - 1 1}$ & $\mathbf{2 0 1 1 - 1 2}$ & $\mathbf{2 0 1 2 - 1 3}$ & $\mathbf{2 0 1 3 - 1 4}$ & $\mathbf{2 0 1 4 - 1 5}$ \\
\hline First Majors & 7,050 & 7,607 & 7,617 & 8,079 & 7,991 \\
Second Majors & 127 & 173 & 173 & 186 & 174 \\
\hline TOTAL & $\mathbf{7 , 1 7 7}$ & $\mathbf{7 , 7 8 0}$ & $\mathbf{7 , 7 9 0}$ & $\mathbf{8 , 2 6 5}$ & $\mathbf{8 , 1 6 5}$
\end{tabular}

Note: This table reports the number of degrees awarded by academic year. First Majors include the most common scenario of one student earning one degree in one Classification of Instructional Programs (CIP) code. In those cases where a student earns a baccalaureate degree under two different degree CIPs, a distinction is made between "dual degrees" and "dual majors." Also included in first majors are "dual degrees" which are counted as separate degrees (e.g., counted twice). In these cases, both degree CIPs receive a "degree fraction" of 1.0. Second Majors include all dual/second majors (e.g., degree CIP receive a degree fraction that is less than 1). The calculation of degree fractions is made according to each institution's criteria. The calculation for the number of second majors rounds each degree CIP's fraction of a degree up to 1 and then sums the total. Second Majors are typically used when providing degree information by discipline/CIP, to better conveys the number of graduates who have specific skill sets associated with each discipline.

\section{TABLE 4H. Baccalaureate Degrees in Programs of Strategic Emphasis (PSE)} [Includes Second Majors]

\begin{tabular}{|c|c|c|c|c|c|}
\hline & $2010-11$ & 2011-12 & 2012-13 & 2013-14 & 2014-15 \\
\hline STEM & 1,572 & 1,844 & 1,987 & 1,975 & 1,914 \\
\hline HEALTH & 446 & 695 & 818 & 1,099 & 1,519 \\
\hline GLOBALIZATION & 243 & 284 & 249 & 284 & 258 \\
\hline EDUCATION & 596 & 570 & 481 & 516 & 366 \\
\hline GAP ANALYSIS & 547 & 513 & 495 & 549 & 568 \\
\hline SUBTOTAL & 3,404 & 3,906 & 4,030 & 4,423 & 4,625 \\
\hline PSE PERCENT OF TOTAL & $47.43 \%$ & $50.21 \%$ & $51.73 \%$ & $53.51 \%$ & $56.64 \%$ \\
\hline \multicolumn{6}{|c|}{$\begin{array}{l}\text { Notes: This is a count of baccalaureate majors for specific Programs of Strategic Emphasis, as determined by the Board of Governors staff with consultation } \\
\text { with business and industry groups and input from universities. This is a count of baccalaureate degrees awarded within specific Programs of Strategic } \\
\text { Emphasis, as determined by the Board of Governors staff with consultation with business and industry groups and input from universities - for more } \\
\text { information see: http://wwww.flogg.edu/pressroom/strategic emphasis/. The Board of Governors revised the list of Programs of Strategic Emphasis in } \\
\text { November 2013, and the new categories were applied to the historical degrees. A student who has multiple majors in the subset of targeted Classification } \\
\text { of Instruction Program codes will be counted twice (i.e., double-majors are included). }\end{array}$} \\
\hline
\end{tabular}




\section{Section 4 - Undergraduate Education (continued)}

\section{TABLE 4I. Baccalaureate Degrees Awarded to Underrepresented Groups}

2010-11 2011-12 2012-13 2013-14 2014-15

Non-Hispanic Black

$\begin{array}{llllll}\text { Number of Degrees } & 875 & 856 & 884 & 888 & 899 \\ \text { Percentage of Degrees } & 13 \% & 12 \% & 12 \% & 11 \% & 12 \%\end{array}$

Hispanic

$\begin{array}{lccccc}\text { Number of Degrees } & 1,033 & 1,268 & 1,285 & 1,493 & 1,554 \\ \text { Percentage of Degrees } & 15 \% & 17 \% & 17 \% & 19 \% & 20 \%\end{array}$

Pell-Grant Recipients

$\begin{array}{lccccc}\text { Number of Degrees } & 3,130 & 3,859 & 4,038 & 4,397 & 4,353 \\ \text { Percentage of Degrees } & 46 \% & 50 \% & 54 \% & 56 \% & 56 \%\end{array}$

Note: Non-Hispanic Black and Hispanic do not include students classified as Non-Resident Alien or students with a missing race code. Students who earn two distinct degrees in the same term are counted twice - whether their degrees are from the same six-digit CIP code or different CIP codes. Students who earn only one degree are counted once - even if they completed multiple majors or tracks. Percentage of Degrees is based on the number of baccalaureate degrees awarded to non-Hispanic Black and Hispanic students divided by the total degrees awarded - excluding those awarded to non-resident aliens and unreported.

Pell-Grant recipients are defined as those students who have received a Pell grant from any SUS Institution within six years of graduation - excluding those awarded to non-resident aliens, who are only eligible for Pell grants in special circumstances. Percentage of Degrees is based on the number of baccalaureate degrees awarded to Pell recipients, as shown above, divided by the total degrees awarded - excluding those awarded to non-resident aliens.

Notes on Trends: In 2007, the US Department of Education re-classified the taxonomy for self-reported race/ethnicity categories and allowed universities a two-year phase-in process before all institutions were required to report based on the new categories for the 2011-12 academic year. This reclassification will impact trends. 


\section{Section 4 - Undergraduate Education (continued)}

\section{TABLE 4J. Baccalaureate Degrees Without Excess Credit Hours}

\begin{tabular}{lccccc} 
& $\mathbf{2 0 1 0 - 1 1}$ & $\mathbf{2 0 1 1 - 1 2}$ & $\mathbf{2 0 1 2 - 1 3}$ & $\mathbf{2 0 1 3 - 1 4}$ & $\mathbf{2 0 1 4 - 1 5}$ \\
\hline FTIC &. & $56 \%$ & $53 \%$ & $60 \%$ & $64 \%$ \\
\hline AA Transfers &. & $58 \%$ & $66 \%$ & $71 \%$ & $72 \%$ \\
\hline Other Transfers &. & $39 \%$ & $50 \%$ & $57 \%$ & $59 \%$ \\
\hline TOTAL &. & $\mathbf{5 2 \%}$ & $\mathbf{5 6 . 6 5 \%}$ & $\mathbf{6 2 . 7 7 \%}$ & $\mathbf{6 5 . 0 5 \%}$
\end{tabular}

Notes: This table is based on statute 1009.286 (see link), and excludes certain types of student credits (e.g., accelerated mechanisms, remedial coursework, non-native credit hours that are not used toward the degree, non-native credit hours from failed, incomplete, withdrawn, or repeated courses, credit hours from internship programs, credit hours up to 10 foreign language credit hours for transfer students in Florida, and credit hours earned in military science courses that are part of the Reserve Officers' Training Corps (ROTC) program). This metric is not the same as the Excess Hours Surcharge, which has multiple cohorts with varying fee rates. This table reports the percentage of baccalaureate degrees awarded within $110 \%$ of the catalog hours required for a degree based on the Board of Governors Academic Program Inventory. This calculation is based on Hours To Degree data submitted by universities to the Board of Governors and excludes recent graduates who have already earned a baccalaureate degree. Note*: Improvements were made to data collection process beginning with 2012-13 data to better account for high school dual enrolled credits that are exempt from the excess hour calculation. Also, 2012-13 data marked a slight methodological change in how the data is calculated. Each CIP code's required number of 'catalog hours' was switched to the officially approved hours as reported within the Board of Governors' Academic Program Inventory - instead of the catalog hours reported by the university on the HTD files.

\section{TABLE 4K. Undergraduate Course Offerings}

$\begin{array}{cccccc} & \text { Fall 2010 } & \text { Fall 2011 } & \text { Fall 2012 } & \text { Fall 2013 } & \text { Fall 2014 } \\ \begin{array}{c}\text { Number of } \\ \text { Course Sections }\end{array} & 2,545 & 2,547 & 2,532 & 2,471 & 2,430\end{array}$

\section{Percentage of Undergraduate Course Sections by Class Size}

\begin{tabular}{lccccc}
\hline Fewer than 30 Students & $56 \%$ & $59 \%$ & $59 \%$ & $56 \%$ & $60 \%$ \\
\hline 30 to 49 Students & $28 \%$ & $26 \%$ & $26 \%$ & $28 \%$ & $25 \%$ \\
\hline 50 to 99 Students & $12 \%$ & $11 \%$ & $11 \%$ & $11 \%$ & $10 \%$ \\
\hline 100 or More Students & $4 \%$ & $4 \%$ & $4 \%$ & $5 \%$ & $5 \%$
\end{tabular}

Notes: This data is based on Common Data Set (CDS) definitions. According to CDS, a "class section is an organized course offered for credit, identified by discipline and number, meeting at a stated time or times in a classroom or similar setting, and not a subsection such as a laboratory or discussion session. Undergraduate class sections are defined as any sections in which at least one degree-seeking undergraduate student is enrolled for credit. Exclude distance learning classes and noncredit classes and individual instruction such as dissertation or thesis research, music instruction, or one-to-one readings. Exclude students in independent study, co-operative programs, internships, foreign language taped tutor sessions, practicums, and all students in one-on-one classes. 


\section{Section 4 - Undergraduate Education (continued)}

TABLE 4L. Percentage of Undergraduate Credit Hours Taught by Instructor Type

\begin{tabular}{lccccc} 
& $\mathbf{2 0 1 0 - 1 1}$ & $\mathbf{2 0 1 1 - 1 2}$ & $\mathbf{2 0 1 2 - 1 3}$ & $\mathbf{2 0 1 3 - 1 4}$ & $\mathbf{2 0 1 4 - 1 5}$ \\
\hline Faculty & $66 \%$ & $68 \%$ & $66 \%$ & $67 \%$ & $65 \%$ \\
\hline Adjunct Faculty & $16 \%$ & $13 \%$ & $16 \%$ & $15 \%$ & $17 \%$ \\
\hline Graduate Students & $17 \%$ & $18 \%$ & $17 \%$ & $17 \%$ & $15 \%$ \\
\hline Other Instructors & $2 \%$ & $1 \%$ & $1 \%$ & $1 \%$ & $3 \%$
\end{tabular}

Note: The total number of undergraduate state fundable credit hours taught will be divided by the undergraduate credit hours taught by each instructor type to create a distribution of the percentage taught by each instructor type. Four instructor types are defined as faculty (pay plans 01,02 , and 22), OPS faculty (pay plan 06), graduate student instructors (pay plan 05), and others (all other pay plans). If a course has more than one instructor, then the university's reported allocation of section effort will determine the allocation of the course's total credit hours to each instructor. The definition of faculty varies for Tables $4 \mathrm{~L}, 4 \mathrm{M}$ and $4 \mathrm{~N}$. For Faculty Teaching Undergraduates, the definition of faculty is based on pay plans 01,02 , and 22.

\section{TABLE 4M. Student/Faculty Ratio}

\begin{tabular}{cccccc} 
& Fall 2010 & Fall 2011 & Fall 2012 & Fall 2013 & Fall 2014 \\
\hline Ratio & 24 & 26 & 24 & 24 & 23 \\
Note: This data is based on Common Data Set (CDS) definitions. This is the Fall ratio of full-time equivalent students (full-time plus $1 / 3$ part time) to full-time \\
equivalent instructional faculty (full time plus $1 / 3$ part time). The ratio calculations exclude both faculty and students in stand-alone graduate or professional \\
programs such as medicine, law, veterinary, dentistry, social work, business, or public health in which faculty teach virtually only graduate-level students. \\
Undergraduate or graduate student teaching assistants are not counted as faculty.
\end{tabular}




\title{
Section 4 - Undergraduate Education (continued)
}

\author{
TABLE 40. Post-Graduation Metrics
}

\section{Percent of Bachelor's Graduates Employed Full-time or Continuing their Education, One Year After Graduation}

\begin{tabular}{lcccc} 
& $\mathbf{2 0 1 0 - 1 1}$ & $\mathbf{2 0 1 1 - 1 2}$ & $\mathbf{2 0 1 2 - 1 3}$ & $\mathbf{2 0 1 3 - 1 4}$ \\
\hline Enrolled or Employed (Full-time) & $69.04 \%$ & $68.00 \%$ & $73.66 \%$ & $74.54 \%$ \\
Enrolled or Employed (Earned \$25,000+) &. &. & $64.87 \%$ & $65.82 \%$ \\
Number of States included in Search & 1 & 36 & 38 & 38 \\
Percent Found & $91 \%$ & $89 \%$ & $91 \%$ & $92 \%$
\end{tabular}

Notes: Enrolled or Employed Full-Time is based on the number of recent baccalaureate graduates who are either employed full-time or continuing their education within one year after graduation. Full-time employment is based on those who earned at least as much as a full-time (40hrs a week) worker making minimum wage. Enrolled or Employed (Earning $\$ 25,000+$ ) is based on the number of recent baccalaureate graduates who are either employed and earned at least $\$ 25,000$ or continuing their education within one year after graduation. The employed data includes non-Florida data that is available from the Wage Record Interchange System 2 (known as "WRIS 2") and Federal employee data that is available from the Federal Employment Data Exchange System (FEDES) initiative. Military employment data was collected by the Board of Governors staff from university staff. Due to limitations in the data, the continuing enrollment data includes any enrollment the following year regardless of whether the enrollment was post-baccalaureate or not. Percent Found refers to the percentage of graduates found in the dataset - including those that did not earn wages above the full-time threshold and those who were found outside of the one-year window.

For more information about the methodology see: http://www.flbog.edu/about/budget/performance_funding.php.

For more information about WRIS2 see: http://www.doleta.gov/performance/wris 2.cfm.

For more information about FEDES see: http://www.ubalt.edu/fif/fedes/.

\section{Median Wages of Bachelor's Graduates Employed Full-time in Florida, One Year After Graduation}

\begin{tabular}{lcccc} 
& $\mathbf{2 0 1 0 - 1 1}$ & $\mathbf{2 0 1 1 - 1 2}$ & $\mathbf{2 0 1 2 - 1 3}$ & $\mathbf{2 0 1 3 - 1 4}$ \\
\hline 5th PERCENTILE WAGE & $\$ 17,300$ & $\$ 17,800$ & $\$ 18,400$ & $\$ 18,700$ \\
\hline 25th PERCENTILE WAGE & $\$ 25,200$ & $\$ 25,400$ & $\$ 26,500$ & $\$ 27,200$ \\
\hline MEDIAN WAGE & $\$ 33,200$ & $\$ 34,700$ & $\$ \mathbf{\$ 3 5 , 3 0 0}$ & $\mathbf{3 6 0 , 5 0 0}$ \\
\hline 75th PERCENTILE WAGE & $\$ 44,600$ & $\$ 44,500$ & $\$ 46,800$ & $\$ 48,200$ \\
\hline 95th PERCENTILE WAGE & $\$ 65,500$ & $\$ 67,000$ & $\$ 66,300$ & $\$ 67,700$ \\
\hline Percent Found & $53 \%$ & $51 \%$ & $53 \%$ & $54 \%$ \\
\hline
\end{tabular}

Notes: Median Wage data is based on Florida's annualized Unemployment Insurance (UI) wage data for those graduates who earned at least as much as a full-time employee making minimum wage in the fiscal quarter a full year after graduation. This UI wage data does not include individuals who are selfemployed, employed out of state, employed by the military or federal government, or those without a valid social security number. This wage data includes graduates who were both employed and enrolled. Wages rounded to nearest hundreds. Percent Found refers to the percentage of graduates found in the dataset - including those that did not earn wages above the full-time threshold and those who were found outside of the one-year window. 


\section{Section 5 - Graduate Education}

\section{TABLE 5A. Graduate Degree Program Changes in AY 2014-15}

\begin{tabular}{|l|l|l|l|l|l|l|}
\hline \multicolumn{1}{|c|}{ Title of Program } & $\begin{array}{c}\text { Six-digit } \\
\text { CIP } \\
\text { Code }\end{array}$ & $\begin{array}{c}\text { Degree } \\
\text { Level }\end{array}$ & $\begin{array}{c}\text { Date of } \\
\text { UBOT } \\
\text { Action }\end{array}$ & $\begin{array}{c}\text { Starting } \\
\text { or Ending } \\
\text { Term }\end{array}$ & $\begin{array}{c}\text { Date of } \\
\text { Board of } \\
\text { Governors } \\
\text { Action }\end{array}$ & Comments \\
\hline New Programs & 51.0913 & Masters & $6 / 5 / 2014$ & 2015 SUMMER & & \\
\hline Athletic Training & 11.0401 & Masters & $6 / 5 / 2014$ & 2014 FALL & & \\
\hline Information Studies & 51.2314 & $\begin{array}{l}\text { Research } \\
\text { Doctorate }\end{array}$ & $12 / 5 / 2013$ & 2014 FALL & $6 / 19 / 2014$ & \\
\hline Rehabilitation Sciences & & & & & & \\
\hline Terminated Programs & & & & & \\
\hline \multicolumn{7}{|l|}{} \\
\hline \multicolumn{7}{|l|}{} \\
\hline \multicolumn{7}{|l|}{} \\
\hline
\end{tabular}

Note: This table does not include new majors or concentrations added under an existing degree program CIP Code. This table reports the new and terminated program changes based on Board action dates between May 5, 2014 and May 4, 2015.

New Programs are proposed new degree programs that have been completely through the approval process at the university and, if appropriate, the Board of Governors. Does not include new majors or concentrations added under an existing degree program CIP Code.

Terminated Programs are degree programs for which the entire CIP Code has been terminated and removed from the university's inventory of degree programs. Does not include majors or concentrations terminated under an existing degree program CIP Code if the code is to remain active on the academic degree inventory.

Programs Suspended for New Enrollments are degree programs for which enrollments have been temporarily suspended for the entire CIP Code, but the program CIP Code has not been terminated. Does not include majors or concentrations suspended under an existing degree program CIP Code if the code is to remain active on the academic degree inventory and new enrollments in any active major will be reported. Programs included in this list may have been suspended for new enrollments sometime in the past and have continued to be suspended at least one term of this academic year.

New Programs Considered by University But Not Approved includes any programs considered by the university board of trustees, or any committee of the board, but not approved for implementation. Also include any programs that were returned prior to board consideration by the university administration for additional development, significant revisions, or re-conceptualization; regardless of whether the proposal was eventually taken to the university board for approval. Count the returns once per program, not multiple times the proposal was returned for revisions, unless there is a total re-conceptualization that brings forward a substantially different program in a different CIP Code. 
Section 5 - Graduate Education (continued)

TABLE 5B. Graduate Degrees Awarded

\begin{tabular}{lccccc} 
& $\mathbf{2 0 1 0 - 1 1}$ & $\mathbf{2 0 1 1 - 1 2}$ & $\mathbf{2 0 1 2 - 1 3}$ & $\mathbf{2 0 1 3 - 1 4}$ & $\mathbf{2 0 1 4 - 1 5}$ \\
\hline First Majors & 2,800 & 2,943 & 3,007 & 3,179 & 3,501 \\
Second majors & 0 & 0 & 0 & 0 & 0 \\
\hline TOTAL & $\mathbf{2 , 8 0 0}$ & $\mathbf{2 , 9 4 3}$ & $\mathbf{3 , 0 0 7}$ & $\mathbf{3 , 1 7 9}$ & $\mathbf{3 , 5 0 1}$ \\
\hline Masters and Specialist (first majors) & 2,373 & 2,524 & 2,558 & 2,633 & 2,900 \\
Research Doctoral (first majors) & 269 & 271 & 295 & 330 & 321 \\
Professional Doctoral (first majors) & 156 & 146 & 153 & 216 & 280 \\
\hline Dentistry & 0 & 0 & 0 & 0 & 0 \\
Law & 0 & 0 & 0 & 0 & 0 \\
Medicine & 109 & 112 & 106 & 120 & 124 \\
\hline Nursing Practice & 12 & 6 & 5 & 6 & 12 \\
Pharmacy & 0 & 0 & 0 & 0 & 49 \\
Physical Therapist & 35 & 28 & 42 & 90 & 95 \\
\hline Veterinary Medicine & 0 & 0 & 0 & 0 & 0 \\
Other Professional Doctorate & 0 & 0 & 0 & 0 & 0
\end{tabular}

Note: This table reports the total number of graduate level degrees that were awarded by academic year as well as the number by level. The table provides a breakout for the Professional Doctoral degrees.

\section{TABLE 5C. Graduate Degrees Awarded in Areas of Strategic Emphasis}

[Includes Second Majors]

\begin{tabular}{lccccc} 
& $\mathbf{2 0 1 0 - 1 1}$ & $\mathbf{2 0 1 1 - 1 2}$ & $\mathbf{2 0 1 2 - 1 3}$ & $\mathbf{2 0 1 3 - 1 4}$ & $\mathbf{2 0 1 4 - 1 5}$ \\
\hline STEM & 648 & 724 & 837 & 929 & 1,085 \\
\hline HEALTH & 744 & 729 & 762 & 838 & 1,050 \\
\hline GLOBALIZATION & 27 & 31 & 29 & 25 & 42 \\
\hline EDUCATION & 475 & 496 & 432 & 385 & 386 \\
\hline GAP ANALYSIS & 55 & 66 & 90 & 97 & 107 \\
\hline SUBTOTAL & 1,949 & 2,046 & 2,150 & 2,274 & 2,670 \\
\hline PSE PERCENT OF TOTAL & $\mathbf{6 9 . 6 1 \%}$ & $\mathbf{6 9 . 5 2 \%}$ & $\mathbf{7 1 . 5 0 \%}$ & $\mathbf{7 1 . 5 3 \%}$ & $\mathbf{7 6 . 2 6 \%}$
\end{tabular}

Notes: This is a count of graduate degrees awarded within specific Areas of Strategic Emphasis, as determined by the Board of Governors staff with consultation with business and industry groups and input from universities. This is a count of graduate degrees awarded within specific Programs of Strategic Emphasis, as determined by the Board of Governors staff with consultation with business and industry groups and input from universities - for more information see: http://www.flbog.edu/pressroom/strategic emphasis/. The Board of Governors revised the list of Programs of Strategic Emphasis in November 2013, and the new categories were applied to the historical degrees. A student who has multiple majors in the subset of targeted Classification of Instruction Program codes will be counted twice (i.e., double-majors are included). Note: The denominator used in the percentage includes second majors. 


\section{Section 6 - Research and Economic Development} TABLE 6A. Research and Development

2009-10 2010-11 2011-12 2012-13 2013-14

\section{R\&D Expenditures}

Total (S\&E and non-S\&E)

$(\$ 1,000$ s)

$\$ 385,029$

$\$ 394,963 \quad \$ 443,206$

$\$ 459,409$

$\$ 488,641$

Federally Funded

(\$1,000s)

$\$ 243,017$

$\$ 243,030$

$\$ 236,148$

$\$ 225,414$

$\$ 222,790$

Percent Funded

From External Sources

$70 \% \quad 70 \%$

$63 \%$

$59 \%$

$60 \%$

Total R\&D Expenditures

Per Full-Time, Tenured,

Tenure-Earning Faculty Member (\$)

$\$ 363,921$

$\$ 394,963$

$\$ 433,665$

$\$ 464,049$

$\$ 484,763$

\section{Technology Transfer}

Invention Disclosures

Licenses \& Options Executed

Licensing Income

Received (\$)

Number of Start-Up Companies
2009-10

161

37
$\$ 17,411,625$

5

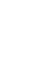

2010-11

2011-12

2012-13

185

288

52

75

91

190

36

2013-14

$\$ 1,390,871$

$\$ 1,243,425$

$\$ 1,802,233$

$\$ 1,405,713$

2010

2011

2012

2013

2014

U.S. Patents Issued [REVISED]

88

89

84

98

110

Notes: R\&D Expenditures are based on the National Science Foundation's annual Survey of R\&D Expenditures at Universities and Colleges (data include Science \& Engineering and non-Science \& Engineering awards). Percent Funded from External Sources is defined as funds from federal, private industry and other sources (non-state and non-institutional funds). Total R\&D expenditures are divided by fall, full-time tenured/tenure-track faculty as reported to IPEDS (FGCU includes both tenured/tenure-track and non-tenure/track faculty). The fall faculty year used will align with the beginning of the fiscal year (e.g., 2007 FY R\&D expenditures are divided by fall 2006 faculty). Invention Disclosures reports the number of disclosures made to the university's Office of Technology Commercialization to evaluate new technology - as reported on the Association of University Technology Managers Annual (AUTM) annual Licensing Survey. Licenses \& Options Executed that were executed in the year indicated for all technologies - as reported by AUTM. Licensing Income Received refers to license issue fees, payments under options, annual minimums, running royalties, termination payments, amount of equity received when cashed-in, and software and biological material end-user license fees of $\$ 1,000$ or more, but not research funding, patent expense reimbursement, valuation of equity not cashed-in, software and biological material end-user license fees of less than $\$ 1,000$, or trademark licensing royalties from university insignia - as reported on the AUTM survey. Number of Start-up Companies that were dependent upon the licensing of University technology for initiation - as reported on the Association of University Technology Managers Annual Licensing Survey. REVISED: US Patents Issued awarded by the United States Patent and Trademark Office (USPTO) by Calendar year. 